\title{
Aportes del Seminario de Historia Rural Andina a la Historia del arte peruano (1978-2015)
}

\author{
Omar Gonzalo Esquivel Ortiz \\ omar.esquivel@unmsm.edu.pe \\ Universidad Nacional Mayor de San Marcos \\ Facultad de Ciencias Sociales \\ Instituto Seminario de Historia Rural Andina
}

\section{SUMILLA:}

El presente artículo está dedicado a identificar los aportes bibliográficos que el Seminario de Historia Rural Andina ha proporcionado a la historia del arte peruano desde sus primeras décadas de actividad, hasta la actualidad. Trazaremos una trayectoria editorial de los perfiles investigativos de los directores más influyentes en esta materia, Pablo Macera y Nanda Leonardini, cuyos continuos progresos y sólidos aportes están encabezados por la novedad académica y la divulgación íntegra de fuentes de primera mano, tanto documentales como artísticas. Estructurado por materias de estudio, repasaremos las contribuciones bibliográficas más representativas de arte popular, arte amazónico, arte del Perú antiguo, arte virreinal, arte republicano y arte contemporáneo, donde destacaremos el papel de las metodologías de análisis plástico de obras, géneros y estilos artísticos, así como los trabajos dedicados a los componentes cruciales del sistema artístico como la crítica y las instituciones de formación artística. Asimismo, trazamos un cuadro clasificatorio y la relación bibliográfica de los 104 títulos dedicados al arte y la historia del arte peruano, a fin de que en el futuro constituya una sección especializada y de consulta en el fondo bibliográfico del SHRA.

Palabras-clave: Arte peruano; Historia del arte peruano; Seminario de Historia Rural Andina; Pablo Macera; Nanda Leonardini.

\section{Contributions of the Seminario de Historia Rural Andina to Peruvian Art History (1978-2015)}

\section{ABSTRACT:}

This article present a bibliographical contribution to Peruvian art by scholars of the Seminario de Historia Rural Andina since the decade of 1970, in particular, the influential studies of Pablo Macera and Nanda Leonardini. Outstanding studies include 104 publications concerning pop art, Amazonian, viceroyalty, republican and contemporary art based on particular methodological criteria.

Keywords: Peruvian art; History of Peruvian art; Seminar of Andean Rural History; Pablo Macera; Nanda Leonardini. 


\section{Introducción}

$\mathrm{L}$ a historia del arte es una disciplina que determina si un objeto artístico puede o no considerarse una obra de arte, es por ello una ciencia humanística que identifica y entrega objetos de estudio a otras ciencias aplicadas al arte, tales como la Antropología, la Filosofía, la Psicología o la Sociología, ${ }^{1}$ no obstante, en nuestro contexto suele suceder lo contrario debido a un complejo problema educativo y de voluntad política que ha aislado su formación y atrasado su actividad investigativa.

Aunque no exista en el Perú carrera con título "Historia del arte", desde 1948 hasta la actualidad, la Universidad Nacional Mayor de San Marcos, mediante el Instituto de Arte de la Facultad de Letras (hoy Escuela Académica de Arte), ha formado a historiadores del arte a través de un plan lectivo cuya base teórica, metodológica y perspectiva crítica sobre las expresiones artísticas más representativas de Europa, Latinoamérica y el Perú, ha dado como resultado 55 tesis sustentadas, ${ }^{2}$ las cuales han abierto pioneros campos de estudio en museología, ${ }^{3}$ arte textil ${ }^{4}$ e iconografía del antiguo Perú, ${ }^{5}$ qeros coloniales,${ }^{6}$ pintura, ${ }^{7}$ azulejos, ${ }^{8}$ y grabado virreinal $;{ }^{9}$ pintura,${ }^{10}$ indumentaria, ${ }^{11}$ escultura $^{12}$ y enseñanza artística en el período decimonónico, ${ }^{13}$ artes gráficas, ${ }^{14}$ performance, ${ }^{15}$

1 Pächt 1993: 10.

2 Entre el período de 1969 y 2015, según registra el catálogo actualizado del Fondo de Tesis de la Biblioteca de la Facultad de Letras y Ciencias Humanas de la Universidad Nacional Mayor de San Marcos.

3 Eficacia de la rotulación en las exposiciones, tesis de bachiller escrita por Dora Felices (1976), Ideología y colección: historia del museo nacional 1822-1830, tesis de licenciatura escrita por David Vargas T. (2008), y Diseño museográfico y su aplicación por estudiantes en la escuela de folklore José María Arguedas de Lima, tesis de licenciatura escrita por Pio Contreras (2014).

$4 \quad$ El manto blanco de Paracas, tesis de licenciatura escrita por Carina Sotelo (2015).

5 Spondylus, una simbología de trascendencia plástica, tesis de licenciatura escrita por Ruth Piedra (2015).

6 El Quero Colonial: elemento de unidad cultural en los andes (Siglo XVII), tesis de licenciatura escrita por Víctor Velezmoro (1998).

7 Como La Pintura en Lima de 1550 a 1640, primera tesis de bachiller escrita por Francisco Stastny Mosberg (1969), Fuentes para la historia del arte en el Perú en las primeras relaciones y crónicas (1527-1571), tesis de bachiller escrita por Martha Barriga (1976), el pintor Cristóbal de Aguilar, tesis de bachiller escrita por Juan Luna (1979), los Retratos de monjas del Monasterio Limeño... de la Concepción, tesis de licenciatura de Mónica Guerrero (2005) y Los árboles de la vida y de la muerte y la escala mística en la pintura Virreinal, tesis de licenciatura de Virgilio F. Cabanillas (2010).

8 Juan del Corral y la azulejería limeña del siglo XVII, tesis de licenciatura de Luis Ramírez (2002).

9 Fray Miguel Adame de Montemayor: grabador y pintor del siglo XVIII, tesis de licenciatura de Susana Vargas (2007).

10 José Olaya: la obra disímil en la producción pictórica de José Gil de Castro, tesis de licenciatura escrita por Patricia Mondoñedo (2002), La Pintura de miniatura en Lima durante la primera mitad del S. XIX, tesis de licenciatura escrita por Mary Takahashi (2004), y Estudio Histórico, formal e iconográfico del retrato de simón bolívar hecho por Pablo Rojas en 1825, tesis de licenciatura escrita por Omar Esquivel (2015).

11 El vestido femenino limeño de élite durante la era del guano (1845-1878), tesis de licenciatura escrita por Angélica Brañez (2004).

12 Escultura civil público-estatal en Lima de 1852 a 1860, tesis de licenciatura escrita por Daniel Vifian (2014), Proyectos estatales y privados para erigir un monumento público al general José de San Martín en Lima y Callao (1822-1921), tesis de licenciatura escrita por Rodolfo Monteverde (2014).

13 Academia Concha: 1890-1918, tesis de licenciatura escrita por Sofía Pachas (2005).

14 La Caricatura política en el Perú: Julio Málaga Grenet, Francisco González Gamarra y Jorge Vinatea Reinoso, tesis de licenciatura escrita por Oscar Luna (2005), Semanario El Perú Ilustrado (1887 - 1892), tesis de licenciatura escrita por Patricia Victorio (2009), y La fantasía tenebrosa en la novela gráfica de Diego Rondón Almuelle, tesis de licenciatura escrita por Víctor Hugo Asencios (2014).

15 El arte de la performance: Analizando La obra de Elena Tejada Herrera Artista Peruana, tesis de licenciatura escrita por Teresa Arias (2010) 
teatro,${ }^{16}$ cine,${ }^{17}$ arte amazónico, ${ }^{18}$ arte popular ${ }^{19}$ y filosofía del arte,${ }^{20}$ investigaciones de laudables méritos que por mala praxis de algunas instituciones no han sido debidamente citadas, por lo que la escuela de Arte sanmarquina, además de ser un reducto profesional, ha cedido al aislamiento dentro del circuito de divulgaciones académicas.

La historia del arte peruano se ha escrito desde tribunas exclusivas y generalmente por historiadores que generan conocimientos dentro de una esfera reservada a la cotización y tráfico de obras artísticas, en la que participan instituciones financieras y museos como sus principales impulsores editoriales. Las revistas de humanidades y letras por ello han servido de medios difusivos para nuestra disciplina, lento caudal que en la actualidad recibe el empuje de revistas especializadas como Illapa (Centro Cultural de la Universidad Ricardo Palma) y Kaypunku, escenario que sin embargo, cuenta aún con una ínfima proporción de investigaciones universitarias publicadas, entre las que se incluyen las del Seminario de Historia Rural Andina, centro de investigaciones dedicada, entre otras disciplinas, al arte y a la historia del arte peruano.

\section{Macera (1966-2000) y Leonardini (2002-2007). Introducción a dos perfiles investigativos}

En noviembre del año 2000, el Seminario de Historia Rural Andina (SHRA) publica Arte peruano del siglo XX, cronología (figura 1), texto que por primera vez introduce en su línea editorial el estudio de expresiones artísticas académicas, el cual fue elaborado por catorce alumnos de la escuela de Arte de la UNMSM y coordinado por la historiadora del arte Nanda Leonardini, docente en la materia de Arte Latinoamericano del siglo XIX desde 1993.

Dedicado "A los estudiantes de la Escuela de Arte de la Universidad San Marcos"21 y con un tiraje de 100 ejemplares, este trabajo pretende de forma explícita: “...entregar un documento compacto, referencial, lleno de datos concisos y exactos, de pureza objetiva... que sirva como fuente de consulta a investigaciones posteriores". ${ }^{22}$ La pionera iniciativa entrega un texto de rigor académico que se aventura a

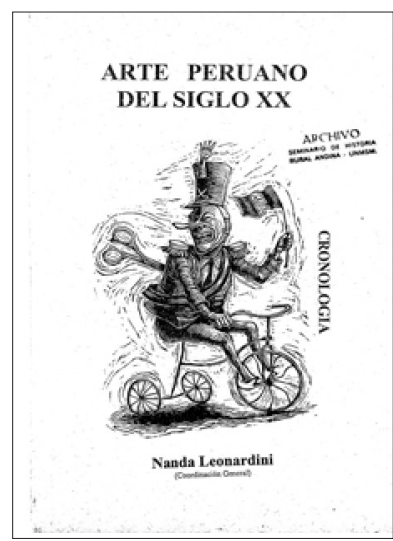

Figura 1. Diseño de portada de Arte peruano del siglo XX. construir una gran línea de tiempo que incluye la mayor cantidad de “actividades [documentadas] relacionadas con las Artes Plásticas” en su mayoría, realizadas en el ambiente artístico limeño de 1900 a 2000. Según la autora:

16 Alfonso La Torre: Su aporte a la crítica teatral peruana, tesis de licenciatura escrita por Sara Joffré (2008).

17 El cine de animación en el Perú. Bases para una historia, tesis de licenciatura escrita por Raúl Rivera (2010).

18 César Calvo de Araújo, el pintor de la selva, tesis de licenciatura escrita por Mónica Solórzano (2006) y Transformación e identidad en la estética amazónica: La pintura sobre Llanchama del artista bora Víctor Churay Roque, tesis de licenciatura escrita por María Eugenia Ylla (2011).

19 El dragón: Influencia China en los trajes de danzas Puneñas actuales, tesis de licenciatura escrita por Marlene Ordoñez (2010), Muebles de embalaje de cuero de la colección del Museo Nacional de la Cultura Peruana, tesis de licenciatura escrita por Estela Miranda (2011), Los chullos de la comunidad de Taquille en Puno y su reconocimiento internacional por UNESCO, tesis de licenciatura escrita por Carla Tapia (2012), La vara de mando popular y tradicional en el Perú, tesis de maestría escrita por Luis Ramírez (2012), y La revitalización del tejido de telar de cintura en la región Lambayeque, tesis de maestría escrita por Zoila Quevedo (2015).

20 La Superación del Dogmatismo Surrealista en los escritos estéticos de Emilio Adolfo Westphalen, una teoría del arte en el Perú del Siglo XX, tesis de licenciatura escrita por Patricio Silva (2010).

21 Leonardini (coord.) 2000: 3

22 Ibíd.: 3 
Conscientes de que nuestra historia del arte peruano está urgida de textos de fácil acceso, es que se facilita este humilde estudio, que no pretende en ningún caso llenar el vacío interpretativo y de análisis, por cierto tan necesarios. ${ }^{23}$

La novedad de los resultados estimula a su coordinadora adoptar y refinar este proyecto como modelo de investigación colectiva para otras publicaciones que realiza a través del SHRA durante y después de su nombramiento como directora de esta institución entre abril de 2002 y setiembre de 2007.

Es a partir de Arte peruano del siglo XX, cronología, que el SHRA asoma un pronto revés en su perfil editorial, el cual deposita especial énfasis en las expresiones plásticas nacionales de siglo XIX y XX, y cuyo método de trabajo además de repercutir directamente en la formación de futuros investigadores para la historia del arte peruano como Fernando Villegas, Sofía Pachas o Rodolfo Monteverde, deja hasta la actualidad uno de los pocos canales de difusión académica nacional para publicaciones sobre arte e historia del arte.

Pero las publicaciones en materia de arte del SHRA no se limitan a este período. Si bien desde 1966 la dirección del doctor Pablo Macera forja un perfil editorial dedicado a las transcripciones completas de fuentes históricas de archivo y a la historia económica del Perú, en la década de 1970 se ocupa de las expresiones artísticas "populares" como nuevo campo de estudio historiográfico y estético, impulsado por el interés de identificar sus relaciones con el arte virreinal de los Andes. Si desde 1978, año en que el SHRA publica La artesanía textil en San Miguel de Pallaques, primer texto en su historia editorial que aborda una expresión artística "popular”, en 1971 Macera ya divulga a través de medios masivos, artículos que cuestionan la categoría "artesanal" o de arte "menor" para: "mates burilados, trabajos en cuero (almofreces, petacas), platería, cerámica, etc." ${ }^{24}$ plantea sus adelantadas hipótesis sobre la continuidad entre la pintura virreinal andina y el "arte popular" en la relación de Tadeo Escalante (principios s. XIX) y los maestros campesinos "primitivos" (s. XIX-XX), y refuerza su hipótesis sobre la resistencia cultural y lucha social que el arte "popular" expresa a través de sus propuestas simbólicas e innovaciones plásticas. ${ }^{25}$ En suma, en 1978, la influencia de Macera determina que el SHRA sea un flanco de estudios de arte "popular", considerándole factor constructivo e influyente en el ideario de nación peruana:

...el arte ha dejado de ser en nuestros espacios urbanos una necesidad socialmente reconocida y se le ha degradado al nivel de las distracciones. Aunque en nuestros sectores rurales el arte siga cumpliendo sus funciones básicas en la realización individual y la socialización dentro del grupo... Debemos poner en evidencia las sucesivas tradiciones artísticas surgidas en la historia andina (de Toquepala a Sabogal y Szyszlo) a fin de que puedan ser libremente asumidas por la sociedad actual y sea probable en el futuro una efectiva sociedad peruana. Sin esa solidaridad múltiple el Perú no existe ni existirá. ${ }^{26}$

Hasta el 2000 las publicaciones del SHRA en materia de arte, son realizadas principalmente desde un enfoque científico social (antropológico, arqueológico e historiográfico) dedicadas a identificar,

Ibíd.: 3

24 Macera 2009: 8

25 Ayacucho: Arte y artesanía. Homenaje al sesquicentenario de la batalla de Ayacucho (1971), Tadeo Escalante y los murales de Acomayo (1974), Retrato de Túpac Amaru (1975), El arte mural cusqueño. Siglos XVI-XX (1975), Las culturas andinas de ayer y hoy (1977) y Pintores populares andinos (1979).

26 Macera 2009: 9. 
seleccionar y registrar fenómenos artísticos a través de un metódico trabajo de campo, algunos de ellos novedosos para la historia del arte peruano, tal es el caso de los textiles de San Miguel de Pallaques (Cajamarca) (1978), la alfarería de Santo Domingo de los Olleros (1981), la relación plástica e histórica entre las "Yllas" y las "Conopas" (1982), la cestería de Cieneguilla (1987), las tablas pintadas de Carmelón Berrocal (Sarhua)(1997) o las pinturas de Víctor Churay (arte bora) (2001). Este último caso de notable importancia debido a la apertura académica hacia el inhóspito arte amazónico, el cual ha repercutido con creces en el medio de las galerías de arte en la presente centuria.

\section{Estadísticas referenciales y ejes de organización}

Desde 1966 hasta la actualidad, el SHRA ha dedicado cerca de la quinta parte de sus publicaciones (104 de 478) a expresiones artísticas que en su tiempo fueron poco o nada atendidas por el medio académico. Sus principales aportes: expresiones novedosas del arte popular andino, el "hallazgo" del arte amazónico y de la actividad femenina en el arte decimonónico, el estado de la escultura en el presente siglo y de la pintura durante el período de independencia nacional, la crítica de arte en Lima de siglo XIX y XX, el arte gráfico contemporáneo, entre otros.

Desde que se publica La artesanía textil en San Miguel de Pallaques (1978) el perfil de investigaciones del SHRA se ha basado, tanto en divulgar la existencia de obras artísticas de interés académico, como de analizar metódicamente sus significados y orígenes, para lo cual se ha servido preferentemente de las ciencias sociales; así hasta 2015, de las 104 publicaciones, 23 son de perspectiva antropológica, 9 arqueológica y 9 historiográfica.

Desde el enfoque de la historia del arte se han realizado 34 textos, a los que se suman 19 compilaciones de obras artísticas y 6 más de diversa clasificación. ${ }^{27}$ Por lo tanto, el conjunto de enfoques disciplinarios permite diferenciar, por un lado, a un grupo de estudios que aplica las ciencias sociales para el análisis de piezas de arte peruano, y por otro, a un conjunto especializado, a su vez subdividido en estudios de Historia del arte peruano y publicaciones de obras artísticas nacionales; el primero dedicado al estudio directo de los componentes del sistema artístico nacional, como la crítica, ${ }^{28}$ el artista y su obra (estudios biográficos y antológicos), ${ }^{29}$ y las instituciones de formación artística ${ }^{30}$ trabajos que suelen incluir análisis especializados de determinados géneros y obras de arte $;^{31}$ y el segundo reúne ediciones compilatorias que reproducen, bajo un propósito divulgativo y de registro patrimonial, valiosos conjuntos de obras artísticas. ${ }^{32}$

De 1978 a 2000, los estudios sociales aplicados al arte alcanzan 36 títulos y 3 publicaciones en arte. Entre 2002 y 2007 se invierten las proporciones a 6 y 29, respectivamente. La intensa producción de textos de arte e historia del arte en solo seis años nos permite identificar claramente el viraje editorial que atraviesa el SHRA durante el cambio de directivas de Pablo Macera a Nanda Leonardini, la una de perspectiva científico-social y la otra científico-humanística.

27 Rengifo (1983), Rodas (1994a, 1994b), Meseldzic (1980), Cuentas (2000) y Pachas (2004).

28 Rengifo (1983), Palomino (2005), Pachas (2009) y Leonardini (2010, 2015).

29 Rengifo (1983), Rodas (1994a, 1994b), Leonardini (2003, 2006, 2010, 2012, 2013, 2014), Leonardini y Pachas (2003), Leonardini y Brañez (2004), Pachas (2004, 2007a, 2008), Palomino (2005), Sierra (2005), Ugarte (2005), Solórzano (2008), Soria (2009), Esquivel (2015), Echevarría (2015).

30 Pachas $(2004,2006,2010)$

31 Leonardini (2001, 2007), Mondoñedo (2002), Debay (2004), Brañez (2005), Corvera (2006, 2009), Takahashi (2006), Soria (2009), Salinas (2010), Esquivel (2015), Echevarría (2015).

32 Berrocal (1997a, 1997b, 1998c), Rojas (2001), Zárate y Ríos (2001), Tácunan y Rojas (2002), Ríos (2003), Casanto (2003, 2005, 2006, 2007, 2008, 2009, 2010, 2013), Casanto y varios (2004), Pachas (2007), Tácunan (2009, 2010). 
Creada en 2002 la vacante para un investigador especializado en historia del arte peruano, la producción de textos permanece constante hasta la actualidad debido a la activa colaboración de Leonardini, quien luego de finalizado su cargo en 2007 publica 7 libros más. Cabe indicar que desde 2008 hasta la fecha, la suma de títulos en arte alcanza a 6 , y en historia del arte a 17 , lo que hace una suma total de 60 títulos publicados entre 2002 y 2015. Si bien el índice de publicaciones por año entre los períodos 2002-2007 y 2008-2015, hasta hoy se reduce a la mitad (de 6 a 3), la actividad investigativa continúa con regularidad.

Por otro lado, las proporciones temáticas demuestran que el arte popular es la principal materia en estudios de arte con 31 títulos (26 producidos en el período Macera), secundado por los de arte contemporáneo con 22 publicaciones (todos producidos por sugerencia o autoría de Leonardini), seguidas por las de arte amazónico (19),

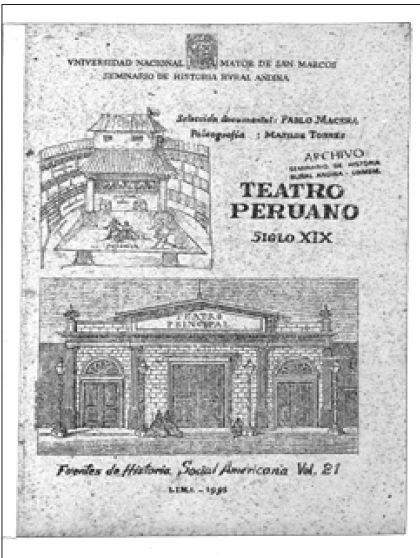

Figura 2. Diseño de portada de Teatro peruano, siglo XIX (Macera 1991). arte republicano (17), arte del Perú antiguo (11) y arte virreinal (4).

Hasta el 2000, de 36 publicaciones en torno al arte peruano, 14 son de enfoque antropológico, 9 arqueológico, 2 historiográfico, 3 artístico ${ }^{33}$ y 4 sin clasificar, las primeras abocadas exclusivamente al arte popular, y las segundas al arte peruano antiguo, lo que demuestra a su vez que son las únicas disciplinas que han intentado aproximarse a estos ámbitos ${ }^{34}$

Un lugar especial ocupan los textos realizados por el Doctor Pablo Macera, producciones nutridas de métodos provenientes de la Antropología, etnografía, Historia e Historia del arte que permiten categorizarse dentro de un orden mixto e independiente, así por ejemplo en el Teatro peruano, siglo XIX (figura 2), Macera selecciona y publica un grupo de expedientes del Coliseo de Comedias con el fin de revelar fehacientes muestras sobre la mentalidad operante en Lima decimonónica. Agrupados en 4 grupos: "economía, vida de actores, relación de obras [teatrales]", y en especial, el "gusto público", el historiador abre y distribuye campos de estudios multidisciplinarios relacionados con la estética social. Este libro, atípico respecto a los que dedica al arte popular, propone como principio de divulgación científica transcribir fuentes historiográficas para el arte del período republicano. En 1997, con Cuentos pintados del Perú, Macera suma otro tipo de publicaciones bajo un formato similar a catálogos de obras de arte, el cual durante los siguientes años es empleado como alerta bibliográfica de obras artísticas no reconocidas en el ámbito académico y no académico.

En suma, la producción bibliográfica de arte peruano puede tener 3 ejes organizativos: Por enfoque disciplinario, por materia de estudio y por tipo de publicación. Por disciplina se diferencian los trabajos derivados de las ciencias sociales y de arte e historia del arte; si para el primer caso se incluyen los de Antropología, Arqueología, Historia, y con mención especial los estudios de Pablo Macera (4 en total); para el segundo se reúnen las reproducciones de obras artísticas, investigaciones especializadas en Historia del arte y los 16 estudios de Nanda Leonardini.

Por materia se diferencian 2 grupos de acuerdo a 2 criterios, uno según la raigambre nativa y la resistencia a las normas estéticas foráneas de las expresiones artísticas andinas (31) y amazónicas

33 Referido a las reproducciones de obras de arte: Los Cuentos pintados del Perú, catálogos de la obra de Carmelón Berrocal (Berrocal 1997a, 1997b, 1997c).

34 De este conteo los 4 títulos faltantes corresponden a la autoría del Dr. Pablo Macera, cuya metodología independiente forma una categoría propia. Ver tabla clasificatoria anexa a este artículo. 
(19), y otro de acuerdo a una clásica cronología histórica que se periodiza en arte del Perú antiguo (11), arte virreinal (4), arte republicano (17) y arte contemporáneo (22).

Por tipo de publicación diferenciamos 3 tipos: 1. Documentos historiográficos, (57) textos donde el investigador conduce y prioriza la lectura directa y sin alteraciones interpretativas de las fuentes orales o escritas que ha recopilado a partir del testimonio de los sujetos u objetos de estudio. 2. Estudios especializados, (28) textos donde el asunto central es un trabajo teórico e interpretativo del investigador de la materia según las metodologías de su disciplina, y 3. Trabajos artísticos, (19) ediciones que reproducen un cuerpo de obras de arte u objetos artísticos en formatos visuales, auditivos o audiovisuales, introducidos por una reseña, estudio preliminar o clasificación. Por lo general, catálogos de obras pictóricas, dibujo, diseños o trabajos de arte gráfico.

\section{Investigaciones de 1978 a 2015. Aportes a la historia del arte peruano}

La capacidad para detectar y observar un fenómeno artístico y para formular un juicio apreciativo de él, no es exclusiva a un historiador del arte, no obstante, el arqueólogo dedicado a periodizar y afiliar estilísticamente un hecho arqueológico a partir de su decoración e iconografía, el antropólogo concentrado en teorizar el significado cosmogónico de un objeto ritual, o el historiador abocado a relacionar el discurso visual de una obra de arte según los fundamentos de una superestructura, ninguno, intenta demostrar o sustentar los factores que determinan la belleza de sus objetos de estudio, resultan enfoques parciales para lo que el historiador del arte intenta demostrar a partir de las propuestas plásticas que dicho fenómeno artístico acuña en la escala de valores estéticos de su tiempo, sea este un objeto, un género, una corriente o un estilo artístico.

Las ciencias sociales aplicadas al arte han demostrado a través de las publicaciones del SHRA que la sensibilidad para detectar un objeto bello y significativo puede ser transversal a cualquiera de sus disciplinas. Citamos el caso del arqueólogo Jaime Miasta, quien por sugerencia de Pablo Macera emprende un estudio alternativo sobre la cestería "marginal" de Cieneguilla (figura 3), ${ }^{35}$ a la que considera un tipo de expresión artística "popular":

La idea general de la realización del estudio fue sugerida por el Dr. Pablo Macera... entonces el Seminario realizaba un trabajo de Arqueología Histórica, en la cabecera de río Lurín... se tuvo noticia sobre los talleres de cestería localizados en la ribera del río; ellos nos permitirían contar con centros artesanales naturales muy cercanos a la Metrópoli.

La cestería es una actividad humilde y cotidiana, y una tradición antigua en los Andes Centrales... Pese a eso no ha sido tocada por los tratadistas de arte popular,

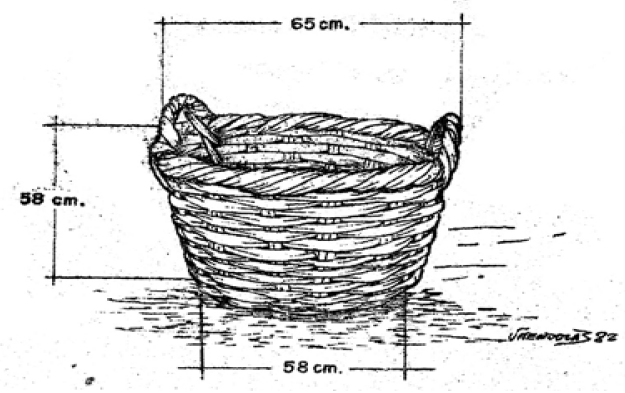

Figura 3. Cesto de Cieneguilla, lámina n. ${ }^{\circ} 66$. tampoco por los Etnólogos ¿Será debido a que estos trabajos son en su mayoría de carácter utilitario y en contadas ocasiones con destino ornamental?36

Pese a ser los únicos comentarios que insinúan la categoría artística de la cestería, los argumentos históricos empleados por Miasta encubren un implícito juicio valorativo basado en la complejidad y diversidad de sus técnicas, y en la posible continuidad de una práctica ancestral subordinada

35 Lámina n. ${ }^{\circ}$ 66. En: Miasta 1987.

36 Miasta y Soto 1987: I, II, 27. Las negritas son nuestras. 
en la actualidad a un estado "marginal". El método del desarrollo histórico le permite ampliar las posibilidades para hallar principios estéticos tradicionales en objetos aparentemente "utilitarios".

La idea impulsada por Macera y el trabajo desarrollado por Miasta ejemplifican el mecanismo de trabajo que se aplicarán en las investigaciones sociales sobre arte "popular" hasta el 2000, aportes bibliográficos que desde sus propios términos profesionales tienen un valor incuestionable para la historia del arte del Perú. En las siguientes líneas citaremos algunos ejemplos representativos por cada materia de investigación a lo largo de la trayectoria del SHRA.

\section{Arte popular}

Si hacia 1978 Macera no tiene dudas sobre el valor plástico del arte "popular” y su discurso de resistencia cultural, las antropólogas Quiroz y Guerra subrayan el valor de intercambio comercial de la "artesanía" dentro del circuito económico provincial y nacional. ${ }^{37}$ Ambas posturas aparentemente disímiles, privilegian la novedad del objeto de estudio como estímulo de sus investigaciones. Tanto esta y otras publicaciones demuestran que bajo la dirección de Macera, el SHRA abre el acceso a nuevas propuestas y perspectivas sobre el arte popular.

En 1980, a través de Los murales de Ambaná (Bolivia) Macera sustenta que la raíz historiográfica, la autonomía estética ${ }^{38}$ y el lenguaje iconográfico del arte popular radican en la "Cultura Andina Colonial". ${ }^{39}$ Bajo este mismo impulso decide explorar la génesis del retablo ayacuchano en Joaquín López Antay (1981), estudio en el cual además de identificar el lazo parental y de influencia artística con el taller de cajonería de San Marcos perteneciente a los Momediano de Antay (de fines de s. XIX), y los factores historiográficos que permitieron la subsistencia de este género a través de la red de intercambio comercial del arrieraje, realiza un análisis formal de las soluciones plásticas que López Antay propone sobre las convenciones estéticas del retablo, en obediencia a su propio lenguaje estilístico cultivado en su quehacer como pintor decorativo de objetos utilitarios (baúles).

Bajo la piel metodológica de la historia del arte, Macera caracteriza los elementos estilísticos de las vertientes del taller Momediano tales como los de la familia Baldeón ${ }^{40}$ o de los Núñez, ${ }^{41}$ a fin de demostrar que el estilo de Antay es un punto intermedio entre sus innovaciones y la herencia tradicional del Cajón San Marcos:

...su originalidad y su genialidad consistió precisamente en admitir todo el peso de esa herencia. Pero López Antay era al mismo tiempo un artista con sus propias intenciones y sus propias convicciones plásticas".

37 Definen artesanía como: “...una actividad productiva en la que el artesano, utilizando el trabajo manual y herramientas rudimentarias; produce artículos para la venta, empleando materiales industrializados o en algunos casos elaborados por él mismo, y el objeto producido lo consideramos como mercancía” Quiroz 1078: 16.

38 Macera concibe la lectura y belleza de estos murales dentro de los códigos de su época. Su método como historiador prioriza el entendimiento de un fenómeno artístico según sus propias convenciones formales. En lugar de cuestionar su calidad, la admite dentro del gusto de su clientela. Afirma: Los “....murales funcionaban como ocasiones y espacios de reconciliación. No solo con los demás sino además cada uno consigo mismo". Este valor social otorgado a la pintura mural no ponía en duda sus convenciones estéticas, por ello poseía intrínsecos "valores formales satisfactorios" Macera 1980: 15.

39 Macera 2009: 95.

40 "Mayores dimensiones del cajón y las imágenes; énfasis de la combinación rojo-a-azul; arcos dibujados en la pared interna del cajón detrás de las imágenes”. Macera 1981: 9.

41 “...prefirió el color amarillo ámbar como si quisiera imprimir a sus figuras de pasta la textura y la luz de las piedras de huamanga... introdujo las columnas en la parte delantera del cajón [a veces] formadas por los cuerpos de dos músicos encima de los cuales, para completar la altura, Nuñez dibujó dos aves... [pudo también] reemplazar los músicos por otros personajes...”. Ibíd. 
Analiza la estructura compositiva del retablo La Trilla, método pionero en el análisis académico de una pieza de arte "popular" peruano (figuras 4 y 5). ${ }^{42}$ A partir de la pregunta: “¿cómo presentar dentro de una misma organización plástica dos temas diferenciados pero que, al mismo tiempo, se relacionan?", Macera determina que la distribución de las figuras del retablo es resultado de una ávida capacidad artística para armonizar pesos visuales respecto a los puntos y áreas de tensión de todo su conjunto.

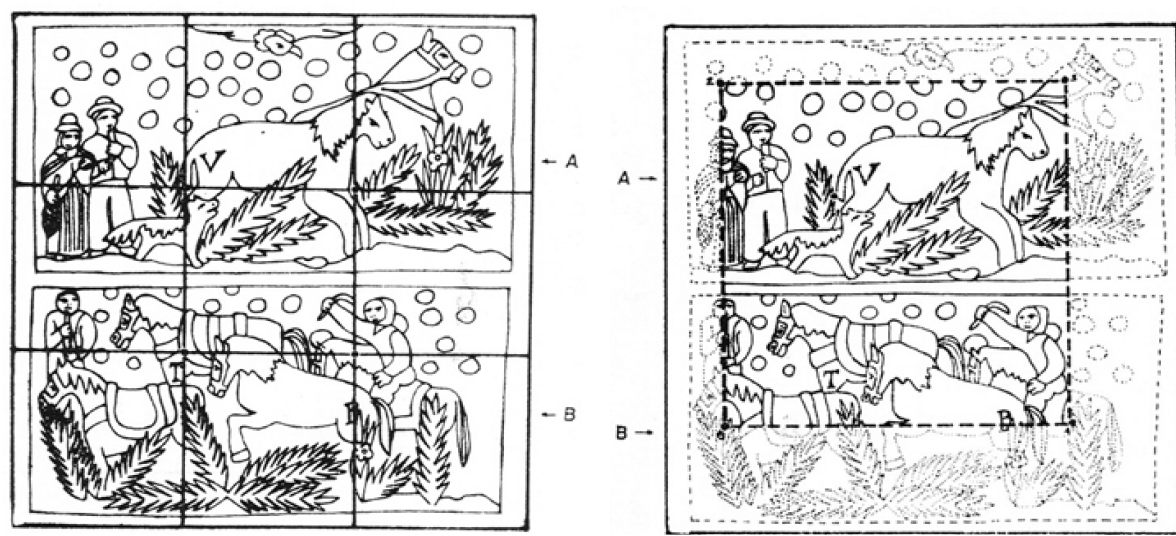

Figuras 4 y 5. La Trilla. Dibujos de Alfonso Respaldiza. La zona media y la línea divisoria concentran el punto de tensión entre ambos registros. Macera resalta la capacidad de López Antay para distribuir zonas de descanso visual en el cielo y la vegetación, cuyo efecto resalta las figuras principales de caballos y campesinos.

El análisis plástico de esta obra dentro de su sentido global y social forjan los argumentos que intentan demostrar la artisticidad de los retablos de López Antay.

Hacia 1981 Macera demuestra que el arte popular andino posee una estética autónoma, incomprendida, y menospreciada. Hasta esta fecha las publicaciones del SHRA se integran al debate y a favor de la autenticidad (y legitimidad) creativa del arte andino popular. En este mismo año Francisco Stastny publica Las artes populares del Perú (1981), estudio que, compatible con los postulados de Macera, categoriza de "arte popular" al retablo y a una numerosa cantidad de piezas anónimas andinas y amazónicas. ${ }^{43}$

En 1984 las investigadoras Prada y Vergara publican Retablo Ayacuchano, tesis de bachiller en Antropología Social de la Universidad San Cristóbal de Huamanga (Ayacucho) sustentada en 1977, pionera en aplicar entrevistas de campo a los retablistas y en reconocer la estética independiente de los retablos ayacuchanos. En sus primeras páginas, las autoras disertan sobre la cualidad "artística" de los retablos, respaldadas en las opiniones críticas de Francisco Moncloa ${ }^{44}$ y Alfonso Castrillón:

42 Macera 1981: 13-14

$43 \mathrm{Si}$ en 1979 Macera define las expresiones artísticas "populares" como la apropiación que el campesinado realiza de las manifestaciones estéticas de una clase dominante provincial (Macera 2009: 105), en 1981, Stastny analiza con mayor profundidad las relaciones plásticas, más allá del intercambio artístico entre clases dominantes y subordinadas. Según el historiador del arte, lo conocido por arte popular no se caracteriza necesariamente por su identificación discursiva con un estrato social sino por la compleja diversidad de intenciones estéticas que toman forma en sus expresiones plásticas (Stastny 1981: 11). El factor de clase que encubre el término "popular", señala además Stastny, no proviene de la identidad social del artista sino del cliente que consume su obra y la define como tal, el mismo que además tienta al artista a seguirle como modelo de "identificación" social, resultado del usufructo y prestigio ideal que este representa ("Lo que cuenta no es el origen noble o campesino, burgués o proletario del artista, sino el grupo social para el cual trabaja y cuyas necesidades artísticas interpreta". Ibíd.: 15). Stastny además agrega que en la dinámica de intercambio entre centros artísticos provinciales ocurren fenómenos de transferencia con el arte nativo campesino, periferias donde surgen innovaciones artísticas, también llamadas "populares" (Ibíd.: 21-23). Observamos entonces que ambas posturas, en su armonía y complementariedad, siguen vigentes en las definiciones de arte popular.

44 “...en el arte no puede haber 'clases', ni artes mayores, ni artes menores. Sólo hay buenos o malos artistas. López Antay es un 
López Antay es un artista y no un artesano... Su obra no es mera repetición de un modelo. López Antay ha modificado y desarrollado la forma heredada, el retablo San Marcos...En López Antay hay más autenticidad que en muchos artistas llamados cultos, que no han hecho más que copiar revistas internacionales toda su vida, saltando de ismo en ismo. ${ }^{45}$

Aunque los argumentos empleados juegan a favor del reconocimiento artístico de López Antay, las autoras lo categorizan de "artesano" debido a sus modos de producción ${ }^{46}$ y su papel estéticofuncional en la economía rural, término que no es cuestionado pero que pretende desvincularse de las connotaciones de clase que comprende lo "popular".

Encuadramos la artesanía artística dentro del arte aplicado y decorativo que se caracteriza por unir los principios utilitarios y estéticos. Dentro de esta categoría está incluida la actividad artística objeto de nuestra investigación: el retablo. ${ }^{47}$

Las antropólogas resuelven que el retablo es una "artesanía artística”, y que su artífice es un "productor" mas no un "artesano artista", al cual muy ocasionalmente se le nombra "artista popular" ${ }_{4} 8$ Las evidentes dificultades terminológicas de este estudio son un importante testimonio de las redefiniciones conceptuales que surgen en el calor del reciente debate de 1975, plantean además como hipótesis que la categoría "artesanías artísticas", diferenciada de "Artesanías productoras de bienes de consumo” y "Artesanías complementarias de la industria”, están conformadas por un amplio grupo de expresiones plásticas junto a la zapatería, la talabartería, la hojalatería, la pirotecnia, la repostería (pensamos en las tanta wawas), la muñequería (o juguetería "típica") y la elaboración de instrumentos musicales. ${ }^{49}$ La novedosa apertura a esta amplia gama de expresiones artísticas es, sin duda, otro de los alcances de esta tesis.

A través de entrevistas, Prada y Vergara recopilan siete biografías de retablistas activos durante la década de 1970, tres de los cuales no son incluidos en Joaquín López Antay (1981)..50 Asimismo, registra la cantidad de colaboradores y aprendices por taller, y su tipo de relación (familiar o contractual) con cada maestro, lo que les permite corroborar que la continuidad de la tradición retablística depende de una exclusiva enseñanza familiar. ${ }^{51}$

A estos alcances se suma la preocupación por las deformaciones plásticas e iconográficas tradicionales que atraviesa el retablo en sus versiones más comerciales:

artista... y en la medida en que un artista se exprese con autenticidad personal y calidad profesional su obra será un testimonio artístico de su sociedad, de su cultura. El artista por serlo de verdad, es pues exponente de una cultura. Es un culto”. Prada y Vergara 1984: II.

45 Ibíd.: III.

46 "...la producción artesanal en sus diversas manifestaciones son ocupaciones que no pueden ser desplazadas por la máquina, porque el arte, en este caso la artesanía artística identifica al hombre. El artesano popular produce su obra que proviene de sus manos y su sensibilidad, que paralela a la industrialización es una fuente económica a la que acude para sobrevivir". Ibíd.: IV-V.

47 Ibíd.: 8 .

48 "Actualmente [en 1977] los artistas populares al igual que los músicos, bailarines, etc, han sido organizados por SINAMOS en la Asociación Nacional de Trabajadores del Arte, que tiene filiales en los departamentos del país. De esta manera se controla orgánicamente a los artistas". Ibíd.: 59.

49 De los 35 oficios artesanales que proponen Prada y Vergara, 25 son considerados como "artesanías artísticas". Citamos en orden alfabético: Alfarería, Alfombrería, Bordaduría, Burilador de mates, Cerámica, Cerería, Ebanistería (muebles), Encajería (confección de mantillas), Filigrana, Herrería, Hojalatería, Juguetería y muñequería (típicas), Peletería, Pirotécnica, Platería, Productor de instrumentos musicales, Productora de flores artificiales, Repostería, Retablería, Talabartería, Tallista, Tallista de coral, nácar, marfil, etc., Tallista en mármol, piedra de Huamanga, sillar, Tejidos y Zapatería. Ibíd.: 8-11.

50 Resaltados en negrita: Jesús Urbano Rojas, Mardonio López H., Heraclio Núñez, Augusto Poma R., Florentino Jiménez, y Juan de Dios Mujica. Ibíd.: 104.

51 Ibíd.: 110. 
Es un hecho real la existencia de algunos artesanos 'inconscientes' que se han iniciado en la retablería, quienes sin el menor miramiento, sólo con fines económicos producen obras carentes de belleza, sentido. Este hecho se debe a la mala influencia del intermediario, con lo cual se desprestigia la expresión artística del verdadero artesano ayacuchano. ${ }^{52}$

Esta tesis demuestra que los estudios antropológicos extraen testimonios clave para el abordaje historiográfico de obras de arte no académicas como el "arte popular" ayacuchano.

Dentro del mismo principio se desarrolla la Artesanía en piedra de Huamanga (1987), título que si bien responde a un parámetro empleado por la disciplina antropológica, deserta ideológicamente al carácter peyorativo de "artesanía”.

Flor Luján intuye que la categoría de obra de arte puede detectarse a través de "atributos" o formulaciones "artísticas". Aunque imprecisa, la autora identifica que las diferencias entre "arte" y “artesanía” se definen más por la diferencia entre el ámbito de enseñanza institucionalizada y el taller familiar.

Existen algunos autores que discrepan al definir artesanía y arte señalando que nada tiene que ver una con la otra...considero que la artesanía es una de las manifestaciones del arte, porque, al igual que el arte [este] es un medio que permite la comunicación entre los hombres (sic). El artesano otorga formas artísticas a los objetos con los cuales trabaja, interpreta una realidad confiriéndole atributos artísticos reflejo de la permanente dialéctica hombre-mundo al igual que cualquier otro artista. La diferencia estaría en que la artesanía a diferencia de las demás formas de arte no tiene una escuela de tipo académico, siendo su escuela el pueblo, y transmitiéndose sus técnicas de generación en generación (de madres a hijos).

Admite en este contexto el carácter artístico de las esculturas:

El tallado en piedra de Huamanga puede clasificarse como arte popular por ser una expresión sencilla y expontánea (sic), practicada caseramente, lejos del ambiente profesional de talleres y academias, cuya técnica es transmitida de generación en generación.

El tallado en piedra de Huamanga es una de las artesanía que aflora en cuanto se habla de Ayacucho... Es en el campo artístico donde se encuentra la más variada e interesante aplicación de la piedra de Huamanga, utilizándose en la fabricación de figurillas de temática religiosa; tal es el caso de los nacimientos, figuras de santos y santas, iglesias, etc. En tallas que cumplen una finalidad de corte decorativo y van desde simples personajes hasta escenas de tipo histórico, económico-social y costumbrista..$^{53}$

De acuerdo a un enfoque materialista, la estructura y metodología de este trabajo analiza cuantitativamente la producción y comercio de las esculturas de Huamanga, su relación crítica con los programas de financiamiento estatal (SINAMOS), la localización de los principales talleres en la provincia de Huamanga y las características demográficas de los maestros (edad, años de trabajo, tipo de relación con los talleres y grado de instrucción). Señala su autora: “... la presente investigación se ha desarrollado desde el punto de la producción y comercialización de productos elaborados en Piedra de Huamanga, para poder llegar de este modo a conclusiones de carácter práctico". ${ }^{54}$

52 Ibíd.: 95-96.

53 Luján 1987: 35-36.

54 Ibíd.: 6. 
Sin embargo, también se encarga de aspectos derivados de sus componentes plásticos e iconográficos. Clasifica las esculturas según sus motivos de representación y uso religioso o decorativo. Deja una detallada lista de los materiales, herramientas y técnicas empleadas por los escultores, al igual que un importante grupo de testimonios biográficos basados en entrevistas personales. ${ }^{55} \mathrm{Su}$ resultado forma un estado general del sistema comercial y productivo de la escultura huamanguina. ${ }^{56}$

La sensibilidad artística ayacuchana no solo es conocida por sus expresiones plásticas sino musicales, rama escasamente comprendida en la historia del arte del Perú. El violín de Isua (1979), el primero de los estudios que recopila el testimonio vivencial y artístico del violinista y migrante Máximo Damián (Lucanas, Ayacucho 1936 - Lima, 2015), es una valiosa fuente informativa que relata las intrínsecas e inseparables relaciones entre la música y el aparato ritual campesino. Aunque no hay modo más eficiente de comprender cualquier expresión sonora sino en el propio acto de oír, el carácter antropológico y de conservación fonológica del habla quechuizada del violinista, nos introduce a un campo de estudio fértil y complejo sobre determinados significados de la música en la ritualidad campesina ayacuchana. Máximo Damián señala en el siguiente ejemplo:

\begin{abstract}
Marcación de vaca hacen con arpa y violín, con corneta, con cacho de vaca. Para eso tene que tener especialmente uno que saber tocar. Ese marcación de vaca hacen con música...Ese San Marcos tene que velar toda la noche con vela. Porque por él hay vaca. Creen ellos que es por él. Es como dueño de la vaca... San Marcos todo eso, ben adornado, ben arregladito va con arpa, con violín, con tinya, con corneta. ${ }^{57}$
\end{abstract}

Hasta finalizar la década de 1980 el SHRA publica 19 títulos de arte popular. El debate entre arte y artesanía suscitado desde 1975 era sin lugar a dudas un cruce obligatorio en los discursos de cada investigador. No obstante, ¿qué posturas habían antecedido a este debate? La estética andina popular analizada de cerca por los indigenistas durante la década de 1930 deja entre los coleccionistas e intelectuales de la década de 1950 una semilla en crecimiento al ritmo de las inmigraciones campesinas a la capital. Con el fallecimiento de José Sabogal en 12 de febrero de 1983, la fortuna crítica se inclina silenciosamente a favor de sus postulaciones y tratados estéticos sobre el arte andino. En este mismo año el SHRA publica El artesano caracterizado por José Sabogal Wiesse, ensayo de Antonio Rengifo que recopila diversos artículos publicados por el pintor entre 1974 y 1982, ${ }^{58}$ cuyo eje crítico en torno a la actividad social y estética del "artesano", no deja diferencias con las del "artista”, excepto por su modo de aprendizaje no académico: "no escolarizado ni mediante manuales; sino [dado] en el mismo proceso de socialización de los niños, tan igual como aprenden a bailar, cantar, etc". ${ }^{99}$ Así para Sabogal la única pero sustancial diferencia entre un artesano y un artista es su aprendizaje dentro un circuito académico oficial. Sin pretensiones de formular una definición de "artista popular", las reflexiones de Sabogal pueden ser el punto de partida para futuras propuestas teóricas y críticas que integren el arte académico con el arte popular peruano.

En 1994, Pablo Macera conoce la obra del pintor de Sarhua, Carmelón Berrocal. Tres años después de activo trabajo se publica la serie de catálogos Cuentos pintados del Perú (1997), ediciones

55 Ibíd.: 71-90.

56 De igual suerte, y basada en esta metodología, Luján también publica Artesanía en madera (Huamanga-Ayacucho) (1987), estudio de una expresión artística andina desatendida por las ciencias sociales y humanas.

57 Gushiken 1979: 81.

58 La mayoría en los diarios La Prensa y Correo. Se suman otras fuentes como Expreso, El Comercio, o las revistas América indígena e Indiana de Alemania occidental).

59 Rengifo 1983: 11. 
cortas en formato de cuentos ilustrados escritos por el propio artista que ofrecen lecturas de la vida cotidiana, cuentos, mitos y entorno natural de Sarhua figurados en nuevos formatos y soportes. Sobre la tradicional verticalidad de las tablas, el uso del maguey, la estructura compositiva en registros, y la ritualidad conmemorativa (genealógica y religiosa), Berrocal introduce el tripley en formato cuadrado, rectangular o de "tondo" para representar con intencionalidad paisajística y con mayores posibilidades cromáticas, las escenas y personajes que encuentra en las investigaciones y revisiones que hace de sus propias tradiciones orales y de su naturaleza. Los catálogos destinados para el Festival de Aarhus en Dinamarca, son la base del proyecto Flora y Fauna de Sarhua. Pintura y Palabra (1997), estudio de mayor aliento dirigido por Macera, con el cual patenta póstumamente la valía estética de las pinturas de Berrocal.

De los 22 años transcurridos desde 1978, Macera consolida a través el SHRA una ribera florida para el arte popular. De los conocidos ejemplos anteriormente citados, podemos incluir algunos estudios más como La tradición alfarera en Santo Domingo de los Olleros (1981), texto que representa con exactitud el principio de rescate y registro que el SHRA propone a través de los testimonios de sus informantes e investigadores, quienes en plena década de 1980 denuncian la alteración, reducción y desaparición de piezas de arte popular.

A través de un estudio historiográfico de las rutas comerciales y del asentamiento del pueblo indígena de Santo Domingo de los Olleros, Quiroz sustenta el vínculo histórico-social entre una desaparecida producción de cerámicas (o callanas) “antiguas” y una línea de piezas de cerámica moderna, de tintes tradicionales con evidentes alteraciones en su morfología y autómata decoración incisa.

Del crisol de tipos de cerámica que encuentra en Santo Domingo de los Olleros ${ }^{60}$ Quiroz identifica y subraya los elementos sincréticos, funcionales y estéticos del "Zahumerito de cuculî"61 (figura 6):

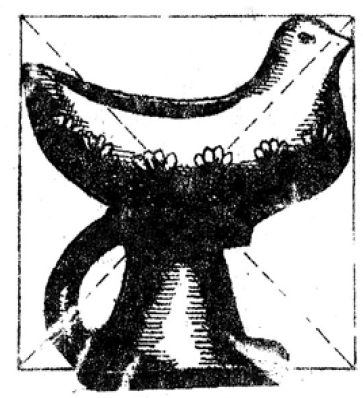

Figura 6. Zahumerito de cuculí. Dibujo de Vicente Mendoza para la portada de La tradición alfarera en Santo Domingo de los Olleros (Quiroz 1981).

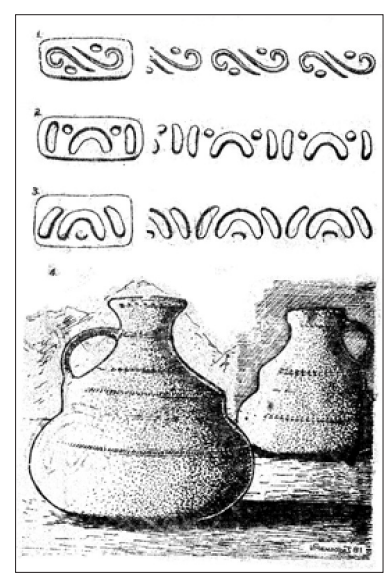

Figura 7. Shakaña. Dibujo de Vicente Mendoza numerado como lámina XVIII en La tradición alfarera en Santo Domingo de los Olleros (Quiroz 1981).

60 Clasifica los tipos de cerámica en Pampana, Olla, Ollita, Tostadora, Plato común ollerano, Cantarito, Shakaña, Yumpu, Jarra, Frutera, Calentadora, Olla de cuatro asas, Zahumerito simple y el Zahumerito de cuculí. Quiroz 1981: 33.

61 "Es la pieza más complicada en su manufactura e íntegramente modelada. El cuerpo del pebetero es doble y consiste en una caja troncocónica comunicada por agujeros con la vasija escultórica de la cual es el pie y el brasero. Se le alimenta de brasas por una abertura trapezoidal a manera de puerta en esa base y el calor que se difunde por dichos agujeros hace zahumar las hierbas aromáticas que se colocan en el recipiente superior. Su estructura es la de un incensario europeo, del cual es muy probable se tomó el modelo y la función, incluso hay referencia de que en un modelo más elaborado dicha 'puertecita’ no se hacía, sino que tenía tapa en forma de criba... Las líneas de la palomita son elegantes y sintéticas. Esta figura representa un sincretismo notable de la cultura dominada con la dominadora, para las cuales la urpi o cuculí y la paloma castilla tiene sendas representaciones ideológicas. En otras partes del país se ha advertido ya esta utilización del pretexto religioso de una, con su religión impuesta, para representar los motivos propios. Ante la actual disminución del culto católico en el pueblo empobrecido, la demanda por el pebetero ha decaído, pero su comercialización se reinicia en la capital”. Ibíd.: 43. 
Quiroz trabaja con los alfareros de Santo Domingo, sus principales informantes, entre los que se incluyen Ernesto Melo y Tomás Belén, este último quien presenta al antropólogo la shakaña (figura 7), un tipo de cerámica extinta de versátiles decoraciones y notable belleza, llamado también por Tello "cántaro andino”: “...el objeto que hayamos visto que más claramente habla de un elevado desarrollo del modelado cerámico en Huarochirí, y [de] la actual decadencia del centro alfarero de la provincia". ${ }^{6}$

Aunque Quiroz basa su estudio de la cerámica en los procedimientos técnicos de elaboración más que en sus elementos estéticos ${ }^{63}$ realiza un registro visual detallado de los sellos decorativos conservados y empleados por Tomás Belén en Santo Domingo ${ }^{64}$

No obstante, recalca las complejas posibilidades compositivas de la técnica del sellado y su relación con un posible lenguaje articulado de "símbolos". ${ }^{5}$

El sellador mismo confecciona sus "muestras", y los diseños son característicos, aunque sobre su composición gráfica [los alfareros] sólo manifiestan que se fundan en "eses y ces". Lo cierto es, como se observa en el conjunto que compone la lámina XX, que la realidad compositiva es más elaborada, guardando relaciones de simetría múltiple. El sugestivo nombre de los sellos parece relacionar el marcado de las piezas con su ornamentación, pero también es plausible la interpretación de que los diseños tengan un contenido denotante propio (y de allí, la acción de mostrar) con lo cual tendrían el carácter de símbolos. ${ }^{66}$

El antropólogo Rodas denomina "artesanos" a los autores de los Tejidos tradicionales de Andahuaylas (1994): “...campesinos que al mismo tiempo son productores de su propia cultura aprendieron este oficio a través de la vida y para la vida, no aprendieron en la escuela, ni bajo la influencia de otros" ${ }^{67}$ Modernidad y tradición, comercio turístico y autoconsumo son dicotomías que de acuerdo a Rodas, definen dos tipos de tejidos, uno con "pallays" y otro carente de ellos o "wayku awaylla”. En este estudio, si bien rescata las técnicas de elaboración, los tipos de tejido y sus significaciones sociales, deposita especial atención al registro de 293 "pallays", motivos que definen el estilo abstracto y geométrico de los tejidos andahuaylinos.

Zilvana Meseldzic publica a través del SHRA Curtido de pieles. Manual elemental (1998) y Pieles y cueros del Perú republicano (2000), dos propuestas que giran en torno al déficit de mercado que atraviesa el artista peletero. El primero de ellos está motivado por fines educativos que optimicen técnica y científicamente los métodos de curtido de pieles. De acuerdo a las consideraciones de la autora:

62 Ibíd.: 59

63 Sobre el sellado, refiere: "En Piedra Grande fue posible observar el sellado. Se realiza en la etapa del pulimento final, con plaquitas de barrio obtenidas por impresión de otra que había sido grabada en bajo relieve con cuñas, de ahí que las llamáramos 'de grabado indirecto', mientras que suponemos hipotéticamente que los sellos (llamados 'muestra en Matará) de los alfareros olleranos, por ser característicamente en bajo relieve (al paso que los matarinos son en alto relieve) han sido grabados directamente”. Ibíd.: 61.

64 Alfarero de Piedra Grande, quien "ejerce el comercio y la docencia en el histórico pueblo de Lahuaytambo y que asimismo fue maestro en Olleros". Ibíd.: 58.

65 Advierte además como hipótesis la relación de transferencia entre los motivos cruciformes de las shicras y la cerámica: "La más expectante de las hipótesis que su vista despertó interés en nosotros es la similitud de composición de los dos motivos que orlan una cruz (lo cual claramente indica la concepción gráfica que guio al grabador) con la decoración textil estructural de las antiguas sicras (shicras, en otra pronunciación) de la provincia”. Ibíd.: 62.

66 Ibíd.: 61-62.

67 Rodas 1994: 2. 
Nuestros artesanos han alcanzado ser los verdaderos artistas en confección peletera pero su curtición que se refleja en la calidad de la piel, era mala. Esto perjudicó especialmente la exportación, en la que además de buen aspecto se exigía un nivel de calidad. ${ }^{68}$

El segundo es un estudio recopilatorio de gacetas, boletines, leyes e inventarios con los cuales desarrolla la trayectoria de la curtiembre de cuero y su papel en la historia económica del período republicano. Meseldzic recalca:

Las artesanías peruanas ya sean por sus artefactos de pieles y cueros, o por su parte creativa y artística, eran siempre admirados por su gusto y habilidad originadas en la tradición indígena. Pero le faltaba desarrollar la parte técnica, sus productos eran de mala calidad, así sucedió que Alemania rechazó diez mil gorras de alpaca peruana ocurriendo algo semejante con Japón. ${ }^{69}$

El rescate de algunas artes tradicionales a través del registro y estudio del testimonio oral de los propios artistas "populares" es uno de los principios rectores de las investigaciones realizadas entre 1978 y 2000, el mismo que continúa en la siguiente década, aunque con menor intensidad. En 2004 se publica La vida dura y el arte bueno ${ }^{70}$ Recuerdos de Cora Cora recopilación que realiza Sofía Pachas del testimonio gráfico y escrito de Gladis Masco, inmigrante ayacuchana de la provincia de Parinacochas.

Influida por el método de inducción creativa e investigativa que Pablo Macera emplea para estimular la obra de los artistas e informantes colaboradores del SHRA, ${ }^{71}$ Pachas trabaja con el imaginario personal de Masco formado de experiencias sensoriales y perceptivas de su entorno nativo y del medio citadino, las cuales cobran forma escrita y gráfica a través de 27 relatos transcritos en quechua y español. A base de plumones y colores sobre cartulina, Masco elabora 49 dibujos que demuestran su inherente capacidad para expresar armonías cromáticas según el objeto y el tipo de cada escena-relato. Vivencias (1), ${ }^{72}$ historias de familia (1), ${ }^{73}$ creencias $(7),{ }^{74}$ cuentos ${ }^{75}(8)$ o costumbres (12), ${ }^{76}$ toman de protagonista a una vida campesina escenificada en paisajes pintados con hábiles y sencillas soluciones, tres colores le son suficientes a Gladis para transformar la superficie blanca en un idílico campo de cultivo o en una árida falda de montaña.

A diferencia de los anteriores artistas ya citados, Gladis Masco no basa rigurosamente su pintura en una tradición andina "popular", sino en los referentes más próximos a su cultura visual,

68 Meseldzic 1998: 9.

69 Meseldzic 2000: 118.

70 Título sugerido por Pablo Macera, según el testimonio vertido por la autora en la mesa de Historia del arte del XXV Coloquio de San Marcos, en 19 de mayo de 2016.

71 A lo largo de la década de 1990, Macera desarrolla un método inductivo de trabajo con informantes y artistas del Ande y la Amazonía. Si bien para el primer caso puede citarse el trabajo realizado con el retablista ayacuchano Jesús Urbano (1992) en Santero y caminante, para el segundo, podemos mencionar a Lastenia Canayo, shipibo-conibo, y Enrique Casanto, asháninca, quienes en un principio libres de toda influencia académica, recibieron el estímulo cognitivo de Macera por medio de conversaciones y entrevistas de las cuales resultaron encargos remunerados de pinturas, bordados, o la elaboración de algún objeto según las aptitudes y preferencias personales del informante. Un lazo de libre entendimiento mutuo con los informantes es sin duda la herramienta clave de éste método y su propósito de expresar visualmente la estética, el conocimiento oral y las mentalidades de los pueblos originarios, sobre los cuales Macera tiende los hilos conductores de una histórica resistencia cultural.

72 El shock de Fujimori.

73 Los tres molinos de Sallatoma

74 El pueblo de las mujeres, Los pistacos, Los ccarccacha, La laguna de Anccascocha, Los gentiles, El arcoiris y La historia de la Virgen de las Nieves.

75 Dos hermanos, La cabeza voladora, el condenado, El gusano de la papa, El baile de los zorrinos, Una roca en la plaza, y El pleito del pucupucu y el gallo.

76 La construcción de la casa, La herranza de las vacas, Los toros bravos, Los carnavales, Semana Santa, Día de los muertos, La muerte de un angelito, El sembrío de la papa, La cosecha de trigo y La limpia de acequia. 
por lo que consideramos que su trabajo es un aporte hacia una categoría de expresiones artísticas contemporáneas y no académicas.

\section{Arte amazónico}

Un género artístico es una convención plástica y temática que el artista puede preservar o trastocar con nuevas soluciones según las necesidades expresivas que posee y las de su entorno social. Si por un lado López Antay renueva el género artístico del Cajón San Marcos, Víctor y Jairo Churay renuevan la pintura sobre llanchama con nuevas posibilidades figurativas, o aún más allá, Lastenia Canayo, shipiba-coniba; y Enrique Casanto, asháninca, transfieren la figura de los "guardianes" o "dueños", de la pintura a la escultura, semilla que en la actualidad perfila un novedoso género escultórico. Del mismo modo que los trigonolitos (ofrendas hechas en piedra) constituyeron un género escultórico ampliamente extendido en el arte taíno (Islas Antillas, 1000 a 1500 d.C.) y las urnas funerarias en la escultura cerámica de los Marajó (Amazonia ecuatoriana, 1000 a 1500 d. C.), en el ámbito de la Amazonia peruana todavía se practican manifestaciones plásticas engarzadas a conocimientos y rituales ancestrales, estrechamente ligadas al utillaje cotidiano, excepto que su categoría en el medio académico aún no las suscriben totalmente como obras de arte.

El arte amazónico posee un indesligable estado de utilidad y ritualidad. El mayoritario empleo de materiales orgánicos perecibles lo hace a su vez una expresión artística efímera. A la cotidianeidad y vulnerabilidad material de sus piezas se agrega un complejo lenguaje formal de signos y diseños que a los ojos no entrenados de un hombre citadino provocan un natural desconcierto. Nuestro inconsciente apego a los cánones estéticos académicos, sumado a las vagas nociones que todavía poseemos sobre los principios formales de su estética y significados simbólicos, hacen aún del arte amazónico una expresión artística marginal. Sin embargo, no pocos han sido los intentos serios por aproximarse a su sensibilidad plástica.

Si bien el interés por el arte de la amazonia ha sido pasivo y anecdótico hasta los inicios del siglo pasado, el círculo académico de Lima se ocupa recientemente de ella a partir de los trabajos que desde 1997 realiza Pablo Macera con los pintores bora Jairo y Víctor Churay. En Fiestas tradicionales de los Bora (2001), el historiador afirma:

La plástica amazónica de diversos grupos étnicos es todavía casi desconocida en la mayoría de los medios intelectuales peruanos con excepción de aquellos que tienen un directo vínculo de trabajo con ese escenario geográfico cultural... . ${ }^{77}$

A partir de 1997 Macera forma un método de trabajo que consiste en la autogestión investigativa y creativa de informantes amazónicos de diferentes etnias. El patrocinio a sus capacidades artísticas, además de gestar sobre la base de sus conocimientos tradicionales, nuevos canales de expresión como el tejido, el dibujo y la escultura, les permite transmutar sus creencias e imaginarios a un lenguaje figurativo. Tanto palabra e imagen son los pilares antropológicos sobre los cuales Macera rescata la oralidad amazónica conservada en un estado orgánico de interpretaciones y reinvenciones.

En dieciseis años el ISHRA entrega dieciocho publicaciones de arte amazónico, trabajos antropológicos en su mayoría coordinados por la historiadora María Belén Soria, dedicados princi-

77 Churay 2001: 8 . 
palmente al análisis del significado cosmogónico de sus piezas, en cuyos métodos además demuestra un progresivo cambio nominativo de las categorías artesanía/obra de arte y artesano/artista.

En la citada Fiestas tradicionales de los Bora (2001) Soria presenta la funcionalidad ritual de los objetos portadores de imágenes en la parafernalia festiva de los bora, cuya iconografía explica a partir de los testimonios orales y artísticos de los Churay. Entre los objetos estudiados destacan los postes de maloca (vivienda familiar hecha de maderos), el manguaré (instrumento ritual de percusión) y las máscaras. Representa el primer intento aproximativo al sentido simbólico y de valores plásticos de las expresiones bora, tratados todavía en el argot de lo "artesanal".

Según la misma metodología, en Arte shipibo (2001) $)^{78}$ Soria deposita su atención en el testimonio que ofrecen los pintores Roldán Pinedo y Elena Valera acerca del sentido simbólico de cuarenta de sus obras ubicadas en colecciones particulares y estatales. La historiadora destaca la tradicionalidad técnica que ambos pintores defienden a partir de un principio arraigado de auto preservación e intercambio con la naturaleza:

Muchos de nosotros [los shipibos]... No contamos con materiales industriales como bastidores, témperas y pinceles para poder crear nuestro arte, y por eso nos vemos en la necesidad de aprovechar los recursos que el monte nos brinda, así como lo han hecho desde siempre nuestros abuelos. El monte no te pide dinero cuando le vas a cazar un mitayo, sacar alguna yerba medicinal, o tintes naturales, sólo te pide que hagas dieta y rindas tus respetos al espíritu que los cuida. ${ }^{79}$

Soria en lugar de tratar las pinturas de Pinedo y Valera como fenómenos artísticos, se ocupa de ellas como fuentes testimoniales donde subyacen elementos cosmológicos de la "memoria étnica shipiba", ${ }^{80}$ de aquí que dentro de sus parámetros valorativos y evolutivos califica la belleza de sus obras como decorativas, intermedias entre arte y artesanía.

Creemos que la manifestación artística regional de los trabajos de Roldán Pinedo y Elena Valera, marcan una cuarta etapa dentro de la evolución contemporánea de la artesanía shipiba, que habiendo nacido como una manifestación artística exclusivamente utilitaria, devino en utilitaria decorativa, hasta ser ahora solo decorativa recibiendo una serie de innovaciones cuyos límites sólo los artesanos podrán determinar. ${ }^{81}$

Bajo el mismo prisma en Arte y Cultura del Monte (2002), Soria se inclina por una lectura del arte asháninka dentro de un marco económico de subsistencia propiciatoria.

Las manufacturas ashánincas no son simples objetos materiales, sino que reúnen en su concepción una serie de elementos ideológicos y estéticos que provienen de su respetuosa relación con la naturaleza. Esta cultura abarca desde viviendas, hasta textilería y cerámica, y cumple una función utilitaria sin perder la mística expresiva de sus fabricantes. ${ }^{82}$

78 Con primera edición en 1999

79 Pinedo 2001: 6.

80 Ibíd.: 4.

81 Ibíd.: 5 .

82 Casanto 2002: 12 
No obstante, a través de los aportes informativos y plásticos de Enrique Casanto "sobre la artesanía asháninka..." ${ }^{83}$ los conceptos relativos a arte y artesanía empleados por la investigadora encubren un importante cambio en sus parámetros críticos. Afirma:

El asháninca como parte de su esfuerzo por adaptarse a su aislado medio ambiente, desarrolló notables habilidades manuales para producir los objetos necesarios a su supervivencia, los que no sólo tienen un valor utilitario sino que han alcanzado altos grados de plasticidad y estética. ${ }^{84}$

Bajo el influjo de Ticio Escobar y Bruno Illius, Soria sostiene la condición artística de las "artes tradicionales" $\$ 5$, no obstante, cataloga aún de "artesano" a quienes preservan las tradiciones orales y artísticas asháninkas.

En el universo shipibo-conibo la figura del "meraya”, o autoridad mágico-religiosa encargada de transmitir la imaginería tradicional a través de los quenés, ${ }^{86}$ posee también la potestad para transformar o modificar sus esquemas representativos. ${ }^{87}$ Bajo este principio, en Introducción al Mundo Semiótico de los diseños Shipibo-Conibo (2004), Soria defiende la hipótesis de los quené como un posible antiguo sistema comunicativo de significantes gráficos, autónomo del sistema lingüístico y conservado en la actualidad en un estado decorativo de precarios significados. ${ }^{88}$

Del mismo modo que en sus otros estudios, Soria no pretende de ningún modo analizar el arte shipibo-conibo a partir de sus propiedades estéticas pese a que reconoce en el quené una "potencial" fuente creativa y dinámica ${ }^{89}$ e incluye la imponente figura del "meraya", autoridad no sólo mágico-religiosa sino artística, única personalidad que determina el curso de las tradiciones y sus formas de representación, en cuya versatilidad se funde y define la creatividad estética e identidad estilística shipibo-conibo, ${ }^{90}$ de donde han resultado obras como el chomo, cerámica que si bien es considerada por Soria como un modelo de "microcosmos" y protagonista objetual del rito de la ayahuasca, es también una de sus manifestaciones plásticas más representativas. ${ }^{91}$ Constituye un género artístico aún fértil para necesarios análisis de tipo formal y semiótico.

En El discurso de las imágenes: Simbolismo y nemotecnia en las culturas amazónicas (2009), si por un lado Soria intenta sostener teóricamente que los motivos abstractos empleados en las

83 Casanto 2002: 8 .

84 Ibid.: 12

85 Ibid.: 15 .

86 "El meráya poseyó un método para transmitir 'mensajes' (quenés), cuyo sistema semántico nos es hoy todavía inextricable". Soria 2004: 22

87 "El rol de los chamanes es dar validez, representar, reproducir y hacer cambios en lo que constituye la codificación de sus tradiciones... el propósito es informativo, es decir, la transmisión de mensajes que contienen valores y creencias manipulables por toda la comunidad”. Ibíd.: 7.

88 Los contrastes que Soria realiza entre las obras de arte shipibo-conibo, y los antiguos ejemplares de cerámica elaborados en la Amazonía como los de estilo Marajó (Ecuador) y Chama (Brasil), demuestran evidentes relaciones formales, de igual modo con los tokapu inca, a los que atribuye un posible vínculo de influencia. Se suma a su vez la diversidad de sentidos simbólicos que en la actualidad proporciona un mismo motivo en el arte textil (tejido en algodón, cestería y plumaria), la escultura (cerámica y escultura en madera) y la pintura sobre piel, lo cual permite corroborar a la investigadora la compleja polisemia de los quené, alterada además por un acelerado proceso de "aculturación creciente de las poblaciones nativas" (Ibíd.: 8).

89 "[Los quené] revelan el potencial creativo de dicho pueblo... pueden pintarse de color negro sobre la falda blanca de la mujer, o rojo y negro sobre la superficie de una cerámica para tomar masato o tallados en la madera de un remo, y también se presentan como si formaran una telaraña en los dibujos finos azulados de genipa en la cara de las mujeres... ”. Ibíd: 24.

90 “... [Los quené son] signos de identidad étnica, que les ayudan a diferenciarse de los mestizos, blancos, o como dicen ellos, de los indígenas ‘salvajes' o ‘no civilizados'”. Ibíd.

91 “... [El] más importante de los objetos, en el cual se llevan a cabo los diseños, es el gran recipiente para contener chicha llamado Chomo. Éste es utilizado por los meráyas como un modelo del microcosmos. La correspondencia existente entre la nomenclatura de las regiones cósmicas y el de las partes del recipiente llega hasta los pequeños detalles, de modo que el recipiente puede ser utilizado por un chamán incluso como material ilustrativo para fines didácticos. Ibíd.: 52. 
culturas amazónicas son una forma de grafía engranada a un complejo sistema de comunicación visual de significados específicos, por otro admite la artisticidad de quienes consideraba "artesanos/ artesanas" amazónicos, entre ellos a los "murayás” o chamanes shipibo-conibo. En una paráfrasis a Carolyn Heath, resalta:

...una de las tareas de los murayás (chamanes) era conseguir diseños de los espíritus y pasarlos a las mujeres encargadas de su materialización artística. Así, el murayá tiene una función clave en el arte y sobre las ideas religiosas dominantes que quedaban simbólicamente codificadas en diseños y motivos individuales. ${ }^{92}$

El arte y el artista son atributo y portador de un poder político, respectivamente. A través de una paráfrasis a Isabel Arranz, admite que el papel de los artistas nativos: “...fortalece la estabilidad emocional de la comunidad, la cual asume un papel activo frente a la realidad cuando trata constantemente de controlarla, manipularla y dirigirla en beneficio propio" ${ }^{93}$ No obstante, dentro de dicha estructura, la estética es un tópico apartado de la jerarquía de necesidades humanas. Desde estos términos la estética se define como una faceta subsidiaria de las necesidades político-religiosas de una comunidad amazónica, y no intrínseca a ella:

Es preciso no olvidar que los objetos considerados "arte indígena", no fueron creados con un objetivo estético sino que tienen finalidades más complejas en las que participan lo religioso, lo mágico y forman parte importante de la imaginería del grupo humano. ${ }^{94}$

Lo cierto es que la estética no es un objetivo ni un accesorio, sino un principio inherente a la humanidad, que puede o no ser desarrollado de manera compleja en sus distintos campos de expresión cultural.

Si bien la estética amazónica no es una de las ocupaciones de este estudio, y por ello sus conclusiones merecen mayor detenimiento analítico en la historia del arte peruano, los aportes de Soria se basan en organizar, sistematizar y formular hipótesis sobre el significado general de los signos $^{95}$ y colores ${ }^{96}$ en los diferentes grupos lingüísticos de la Amazonía (figura 8). ${ }^{97}$

La metodología de autogestión creativa impartida por Macera desde 1997, y aplicada a informantes amazónicos, da como resultado testimonios que facilitan una lectura introductoria de las mentalidades bora, shipiboconibo y asháninka, ésta última con mayor cantidad de obras artísticas y testimonios gráficos gracias a la prodigiosa memoria visual y dibujo de Enrique Casanto Shingari, contratado por el SHRA, quien publica entre

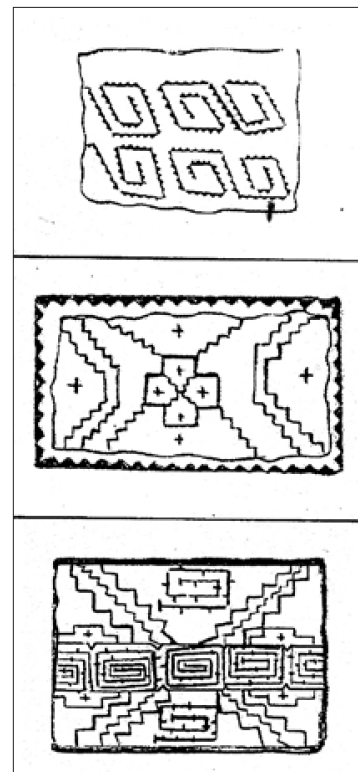

Figura 8. Ejemplos de Caatúva, diseño Bora. En: Simbolismo y nemotecnia en las culturas amazónicas (Soria 2009).

92 Soria 2009: 76.

93 Ibíd.: 78.

94 Ibíd.: 19-20.

95 Reúne un importante repertorio sígnico de las expresiones artísticas más representativas de cada familia lingüística; una suerte de glosario gráfico que permite diferenciar con claridad sus principales rasgos estilísticos. Ibíd.: 95-153.

96 Aporte que identifica el "origen antropocéntrico" del significado semiótico de los colores, tal es el caso del rojo (achiote), signo cromático de temor, fuego, feminidad, salud espiritual. Así también incluye el uso, significado y acepciones en cada comunidad nativa del color amarillo, negro y azul. Ibíd.: 80-94

97 Soria 2009: 117. 
2002 y 2013, 10 libros que recopilan narraciones en su propio idioma y numerosos dibujos de la fauna y flora amazónica, así como su propio imaginario sobre la historia del Perú en La otra historia. Héroes populares del Perú (2004) y un extenso repertorio de Canciones Asháninkas (2013).

Incluimos en esta selección de publicaciones César Calvo de Araujo, el pintor de la selva (2008), pionera investigación de sólido respaldo documental escrita por la historiadora del arte Mónica Solórzano que rescata la olvidada trayectoria de César Calvo, pintor de apasionada vocación por el paisaje y las costumbres amazónicas, y principal referente plástico de una vigente corriente 'selvática' en la pintura académica contemporánea.

Su solitaria actividad pictórica y literaria,${ }^{98}$ su asidua identidad con la amazonia peruana ${ }^{99}$ y sus relaciones con la clase política conducen a Solórzano a escribir un primer capítulo que desarrolla las condiciones del pensamiento y la política nacional dentro de un período efervescente en retóricas indigenistas, donde la mayor pérdida del territorio nacional con Brasil (1909), los conflictos limítrofes con Colombia (1922) y Ecuador (1942), ponen en la palestra política y cultural el tema de la Amazonía a través de la primera exposición amazónica de 1943, realizada en Lima e impulsada directamente por el presidente Manuel Prado.

Si bien algunos pintores indigenistas como Manuel Bernuy Ortiz, Víctor Morey Peña, Américo Pinasco y hasta los propios Sabogal, Codesido, Blas y Brent matizaron su repertorio con algunas escenas exentas del Ande, ninguno encuentra en el entorno selvático un motivo perdurable de su pintura excepto Calvo de Araujo, causa principal de su apartamiento del indigenismo. Macera consecuentemente señala:

En este siglo XX ni siquiera se ha producido un indigenismo amazónico, comparable al indigenismo andino de los años 20-30; aunque fuera con todas sus limitaciones. ${ }^{100}$

En su segundo capítulo, Solórzano reúne a través de entrevistas los testimonios familiares directos y descendientes del pintor. Conforma un cuerpo biográfico y semblanza personal que lo sitúa en los pequeños entornos urbanos de Yurimaguas e Iquitos, reseña su formación personal con el pintor y escultor iquiteño Tito Pinedo Lazo, su instrucción académica en la Escuela Nacional de Bellas Artes (1935-1939), ${ }^{101}$ su convivencia y contacto con los nativos, su participación en el Salón de Independientes de 1940, su primera individual en 1941, ${ }^{102}$ su fama en Brasil, ${ }^{103}$ sus viajes a Estados Unidos y Colombia, su retorno a Lima y retiro definitivo a Pucallpa cinco años antes de fallecer en $1970 .{ }^{104}$

98 Escribe la novela Paiche en 1940 y la publica en Arequipa, en 1963. En ella: "Calvo de Araujo mostraba la difícil subsistencia de las comunidades nativas frente al avance del desarrollo occidental que ocupaba sus territorios restringiendo sus posibilidades de vida. Asume una posición crítica cuando denuncia el abuso en contra de los lugareños, la desordenada explotación de los recursos naturales, el mal gobierno y las leyes...”. Ibíd.: 47.

99 "A las inquietudes propias de su personalidad errante, imposibles de escudriñar, se suma el sentimiento de identidad con su país, reforzado por los constantes enfrentamiento fronterizos; ello fue, probablemente, la causa de su opción por una vida en Lima y no en Brasil donde tenía vinculaciones socioeconómicas y familiares". Ibíd.: 31.

100 Churay 2001: 8 .

101 Señala la investigadora: "Por entonces, la ENBA estaba dirigida por el maestro José Sabogal, quien -molesto ante la negativa del artista de continuar sus estudios- le auguró poca fortuna en la pintura". Solórzano 2008: 31.

102 “...lleva a cabo su primera individual en Lima, en el local de la Asociación Nacional de Escritores, Artistas e Intelectuales del Perú, denominada Motivos de la Selva Amazónica. Presentó entonces sesenta óleos...”. Ibíd.: 33.

103 Donde la crítica le denomina: “...el primer pintor amazónico, en el verdadero sentido de la expresión que el Brasil conoce”. Citado en Ibíd.: 35.

104 "Se ubicaba junto a un pequeño afluente del rio Utiquinía cerca de la ciudad de Pucallpa. Se estableció ahí probablemente a partir de 1965, junto con sus últimos hijos, Ángel, Iván, Tatiana y Rocío... Poco tiempo después contrajo una enfermedad que lo postró los últimos tres o cuatro años, hasta que sus hijos César e Igor lograron convencerle para su traslado a Lima donde falleció, el 
La investigadora organiza la trayectoria de Calvo de Araujo en tres etapas estilísticas bien diferenciadas, acompañadas por una afinidad a temas específicos. De las tres etapas expuestas, basadas en un universo de 418 obras recopiladas, predomina el género paisajístico, con cerca del $50 \%$, “... casi el $27 \%$ costumbres típicas de la selva, retratos alrededor del $15 \%$, mientras que bodegones sólo alcanzan un $5 \%$ del total". ${ }^{105}$

En suma la visión artística que las pinturas de César Calvo de Araujo ofrecen sobre la Amazonía representa su primer ingreso dentro de la sensibilidad estética nacional centralizada en la actividad artística de Lima. Su propuesta artística anticipa el interés por lo amazónico poco más de medio siglo antes que el medio académico. Consideramos por ello que el estudio de Solórzano es una lectura introductoria y obligatoria en cualquier disciplina tratante de las expresiones culturales amazónicas.

\section{Arte del Perú antiguo}

En el Perú ni en el continente la historia del arte cuenta con una metodología precisa que analice los fenómenos artísticos de su antigüedad sin que se incluya su agrafía como un obstáculo en el proceso. Si bien la arqueología ha adoptado el método iconológico sólo hasta su nivel de análisis iconográfico, este aún resulta inestable para abordar una expresión artística cuya naturaleza no desvincula lo puramente gráfico de lo plástico. A estas dificultades se suma que las periodizaciones y caracterizaciones de estilo más clásicas en la historia de la arqueología nacional pocas veces se han sostenido sobre un riguroso análisis de los componentes formales que conforman sus "muestras" u obras artísticas, pese a los tratados bastante conocidos y descontinuados de Jorge Muelle.

Según observaremos en los siguientes textos elaborados por el SHRA, el clásico método de reconocimiento iconográfico durante la década de 1980 es una práctica profesional infrecuente y hasta considerada anticuada, no obstante, sus investigadores revitalizan su aplicación moderna a la par de nuevos métodos de campo. Al final de estas reseñas incluimos además Rimacc Rumi (2015) un reciente estudio de novedoso carácter teórico, al cual consideramos un importante antecedente en el interdisciplinario quehacer arqueológico y de la historia del arte nacional.

De acuerdo a Alberto Rex en Arte, estructura y Arqueología (1979), el ejercicio de la arqueología suele arrastrar el uso del método iconográfico al campo de la libre "fantasía”, privilegia la "clasificación taxonómica y analítica"106 de las piezas arqueológicas de América en lugar de reconocer sus estructuras formales y reconocer patrones simbólicos entre sus expresiones artísticas, cuyo resultado permita sistematizar sus signos y genere la base de "una futura semiología iconográfica precolombina cuyos datos primarios habrá que comenzar por sistematizar, cultura por cultura...", ${ }^{107}$ auxiliada además por las estructura que la etnohistoria y la etnografía pueda reconocer de sus lenguas.

La materia de análisis de Rex se concentra en las relaciones iconográficas entre la figura altiplánica del felino y las del noroeste argentino, en esencia, el primero y hasta segundo grado del análisis iconográfico de Panofsky, sin involucrar un nivel interpretativo o iconológico que identifique el origen y la trayectoria de la figura felínica:

21 de octubre de 1970, luego de permanecer en varios hospitales buscando cura para su mal. Sus restos fueron sepultados en el Cementerio "El Ángel” y se anunció su deceso tanto en algunos medios de prensa de Lima como de Iquitos donde colocaron su nombre a una de las vías más extensas de la ciudad”. Ibíd.: 43.

105 Ibíd.: 49.

106 Rex 1979: 1.

107 Ibíd.: 2. 
Creemos que esta podría ser una pródiga cantera para los investigadores futuros y el punto de partida de este artículo que, más que un estricto análisis estructural, es la descripción de un determinado grupo de signos arqueológicos y de sus relaciones; de significantes más que de significados. ${ }^{108}$

Rex privilegia el hallazgo de conceptos o principios cristalizados en significantes o estructuras sígnicas constituidas a partir de la capacidad creativa del artista. Para el caso del motivo del felino afirma que: “...los elementos integrantes del concepto felino se generan a partir de la concepción plástica de una figura humana o viceversa". ${ }^{109}$ No obstante, en el léxico del autor la "creatividad estética" es un ejercicio exento de tradiciones formales o estructuras, carentes de significaciones, puramente "decorativas". Sobre la figura del felino afirma: La persistencia de sus motivos, la estabilidad de su composición formal dentro de una determinada cultura o Período descarta el mero juego decorativo de la creación estética”. ${ }^{110}$ Por sobre el carácter manual “decorativo”, Rex identifica en la relación hombre-naturaleza, hombre-jaguar, la base conceptual de las representaciones artísticas. Desde su perspectiva, un hecho antropológico conduce al fenómeno artístico.

En 1980, Daniel Morales plantea una periodización evolutiva del centro ceremonial de Pacopampa a partir del hallazgo de fragmentos de cerámica, su análisis estilístico e iconográfico, y las relaciones formales con las características plásticas de Chavín. Señala el arqueólogo como uno de los impulsos de su estudio:

... es cierto que los arqueólogos de las últimas generaciones, en la cual me incluyo, hemos olvidado casi por completo la importancia que puede tener el arte prehispánico como herramienta de análisis de la sociedad andina. Es esta una razón, más que un compromiso para aceptar el reto del Dr. Pablo Macera, y por sugerencia suya, vamos a tratar el tema, tan interesante y que quizás por falta de imaginación la gente joven ha dejado de lado. ${ }^{111}$

Junto a Rex el empleo del método iconográfico y formal sientan un retorno y a su vez renuevan la metodología del análisis arqueológico. Morales y Macera prospectan el análisis del arte del antiguo Perú como una vía para identificar las estructuras del pensamiento andino dentro del marco económico social que particulariza a cada pueblo.

Las contribuciones sobre el estilo... han sido numerosas, dentro de las corrientes difusionistas y funcional-estructuralistas son representativos los siguientes aportes: Uhle (1911-14), Rowe (195860-72), Muelle (1936-37-39-54-60), Lathran (1970), Rex Gonzáles (1979) y otros... [sin embargo] nuestro interés sobre el arte en la cerámica de Pacopampa no es puramente estilístico, en el análisis va implícita pero es secundaria en nuestra interpretación, sólo que por intermedio de ella queremos inferir la evolución de las ideas mágico-religiosa en las culturas andinas, en formación hacia una sólida economía autosuficiente. ${ }^{112}$

En 1982, Ullquis intenta aproximarse a la funcionalidad ritual y fechaje de un género de escultura lítica. El hallazgo de una pieza disímil de este tipo por el arqueólogo Jaime Miasta, impulsa un método de análisis etnohistórico (de crónicas hispanas de la colonia) y etnográfico (de las varian-

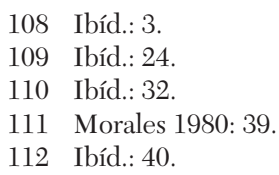


tes lingüísticas que refieran de este tipo objeto) que determine su presencia iconográfica en las culturas andinas. Considerado un objeto ceremonial propiciatorio, el autor determina la presencia panandina del ullqui a partir de sus variantes estilísticas y las configuraciones plásticas que recibe en las regiones más importantes (figura 9), de modo que si en el altiplano recibe el nombre de Ylla, en Cusco se le llama Conopa. Debe ponerse en relieve que Miasta no da el paso definitivo para denominar "artista" al artífice de estas piezas, sino "artesano". El autor si bien deposita mayor importancia al significado histórico de la pieza, aplica un sentido estilístico para determinar sus diferencias y similitudes con otras regiones, el cual permite a la historia del arte identificar la trayectoria de un género artístico.
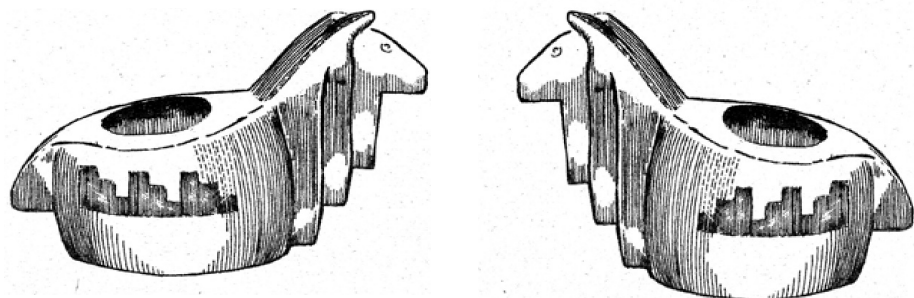

Figura 9. Dibujo de vistas laterales de un ejemplar de Ullqui. En: Ullquis (Miasta 1982).

Hasta 2015 los estudios del arte antiguo del Perú se detienen en favor de otros campos de estudio. En este año el arqueólogo e historiador del arte Gori Echevarría publica Rimacc Rumi. Las Antiguas Quilcas de Lima, tesis de licenciatura que a diferencia de las posturas iconológicas de la década de 1980, propone una metodología basada en el análisis artefactual y formal de las quilcas, el cual consiste en una deductiva secuencia de observaciones al paisaje, al entorno material inmediato, al soporte y al motivo (imagen figurada o quilca) (figura 10). ${ }^{113}$

Propone una definición teórica del término quilca, independiente de la englobante categoría occidental “arte rupestre”. Basado en testimonios etnohistóricos e historiográficos (crónicas), Echevarría señala que el término de quilca posee intrínsecas configuraciones plásticas formuladas por la intencionalidad comunicativa y gráfica del artista, donde escritura e imagen conforman una unidad indivisible, característica de toda expresión estética andina:

Quilca, tal como ha sido comprendido desde el siglo XVI, designa tres

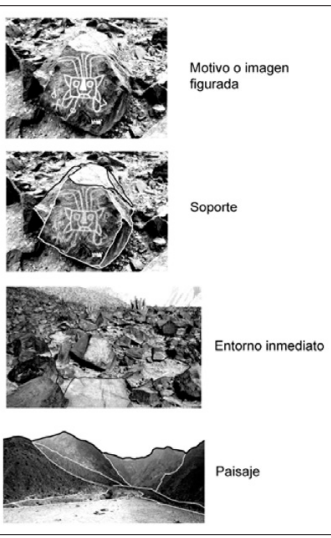

Figura 10. Propuesta de una metodología de análisis artefactual y formal de las quilcas. Gráfico incluido en: Rimacc Rumi (Echevarría 2015) hechos fundamentales: la producción del fenómeno gráfico, el fenómeno gráfico en sí mismo y escritura...la categoría "quilca" es apropiada para describir el fenómeno gráfico sobre roca en el Perú, en todas sus variedades, pero más que eso para describir el fenómeno gráfico cultural de manera genérica en los Andes. En términos teóricos, la amplitud conceptual de esta categoría es necesaria para poder uniformizar el análisis a nivel gráfico-formal y estimar estas manifestaciones culturales con el mismo estatus para todas las variaciones gráficas andinas, independientemente de su soporte, localización o ubicación, para fines de estudio e investigación científica. ${ }^{114}$

113 Echevarría 2015: 27

114 Ibíd.: 33-34. 
Sobre una sólida base crítica, Echevarría emplea un tipo de análisis formal basado en las características genéticas del diseño: líneas, puntos y formas, para generar un criterio de organización basado en unidades morfológicas de diseño y posible significado. Con este fin, uno de los principales criterios de "limpieza" metodológica para periodizar las quilcas es desvincularlas de un mismo período según su lugar de ubicación en común:

Al no existir una referencia directa para la temporalidad [de las quilcas], la cercanía de elementos gráficos no establece la contemporaneidad de los mismos por este hecho; lo cual sería tan absurdo como considerar que todas las pinturas del Museo de Louvre son contemporáneas entre sí únicamente porque se encuentran en un mismo edificio. ${ }^{115}$

Echevarría finalmente propone una cronología sobre la práctica de las quilcas desde 3000 a.C. hasta 1533 d.C., vale decir, concluye que se trata de una expresión artística de trayectoria transversal a la historia del arte del Perú antiguo.

La propuesta sin precedentes, pionera en su campo y en sus formulaciones teóricas, es una de las últimas investigaciones que el SHRA publica en su historia editorial. Forja un importante antecedente para futuras investigaciones interdisciplinarias entre la Arqueología y la Historia del Arte.

\section{El impulso de la historia del arte y la diversificación editorial del SHRA}

El arte popular, el arte amazónico y el arte del antiguo Perú descansan sobre la plataforma editorial que Macera crea hasta fines del siglo pasado. Tras publicarse Arte del siglo XX. Cronología (2000), los principios de rescate documental y de rescate a las personalidades de trascendencia nacional son asumidos por Nanda Leonardini. Para el caso primero incorpora, además de la publicación de fuentes archivísticas para la historiografía del arte, la reproducción fotográfica de obras artísticas, a fin de otorgar legibilidad al análisis y discurso intelectual de cada autor. ${ }^{116}$ Claramente las nuevas herramientas de "imprenta" que emplea el SHRA a partir de 2002 se adscriben a una necesidad metodológica que permite documentar, reproducir y divulgar obras de arte. Las imágenes trascienden su simple carácter ilustrativo.

Debe asimismo recalcarse que hasta el 2002 los investigadores contratados en el SHRA amplían sus horizontes investigativos gracias al fomento de autoría personal que Leonardini deposita para cada libro, así las transcripciones de documentos historiográficos se convierten en una opción paralela a los estudios especializados que cada investigador decida emprender.

Según señalamos anteriormente, el perfil editorial del SHRA se diversifica. A continuación repasaremos los textos más representativos y de mayores aportes a la historia del arte local, según las líneas temáticas: arte virreinal, arte republicano y arte contemporáneo.

115 Ibíd.: 42 .

116 Debe recalcarse que el financiamiento de los materiales de impresión y empaste de los libros es austero hasta la actualidad. Las impresiones están limitadas a fotostáticas sobre papel bond y las tapas se imprimen desde una impresora láser sobre cartulina kimberly, por lo que incluir una sola imagen a color y a bajo costo representa un esfuerzo mayor el cual consiste en recortar y pegar cada lámina según el diagrama de cada texto, similar a un álbum de estampas. Hasta antes de 2002 el proceso era aún más difícil, las impresiones se realizaban con mimeógrafo sobre papel bulky y por cada imagen debía realizarse una plantilla "quemada" por un picador de esténcil electrónico, para finalmente reproducirse al mimeógrafo. 


\section{Arte virreinal}

Durante la década de 1970 y 1980, Pablo Macera dedica una parte de sus investigaciones a la pintura mural andina del virreinato, tópico hasta entonces postergado por los historiadores y la historia del arte. No obstante, solo a partir de 2006 el SHRA abre sus publicaciones al arte virreinal. Aunque hasta la actualidad solo se producen 4 títulos en esta materia, merecen una revista de sus principales aportes.

La mexicana Marcela Corvera publica El Patrocinio. Una leyenda y un esquema artístico medievales ampliamente desarrollados en el virreinato peruano (2006) y El Antiguo Testamento en el arte del Virreinato peruano (2009), dos investigaciones de enfoque formalista que abordan dos de las principales fuentes representativas de la pintura virreinal. En la primera, Corvera reúne un universo de 117 pinturas virreinales peruanas donde identifica la presencia de un esquema figurativo constante en las representaciones marianas, al cual atribuye un significado de "microcosmos" que sintetiza el sistema de patronazgo de los comitentes virreinales: “...indios caciques, autoridades civiles no indígenas, artesanos, clérigos, monjas, frailes, militares, etc.”. 117 De acuerdo a la metodología empleada por la autora, las diferencias y permanencias iconográficas del patrón de estructuras compositivas características del Patrocinio, sirve de guía para hallar en él significaciones sociales particulares y generales. La raíz formal de este tema revela entonces una convención de significados bastante arraigados y sobreentendidos en el pensamiento virreinal.

El segundo es un estudio recopilatorio de 341 obras entre pinturas y esculturas ubicadas en las principales ciudades del virreinato peruano (Lima, Cusco, La Paz, Potosí, Buenos Aires y Bogotá), cuyos temas y figuras relacionadas con el Antiguo Testamento, son, de acuerdo a la autora, reflejo del imperante pensamiento escatológico que caracteriza a la primera generación de evangelizadores y a la segunda de doctrineros. Reúne un importante corpus iconográfico y bibliográfico que refleja el apogeo de un siglo de intensa catequesis indígena.

En El Papel sellado en el Perú Colonial, 1640-1824 (2007), la historiadora Luz Peralta recopila en orden diacrónico y sistemático la mayor cantidad de sellos que la Corona emplea para el membretado de contribuciones, cédulas y diversos documentos de la administración virreinal. Si bien es un texto de enfoque histórico, la autora subraya el rol del sello dentro del reforzamiento del gusto estético local dictado por tendencias artísticas de la corte española (figura 11): ${ }^{118}$
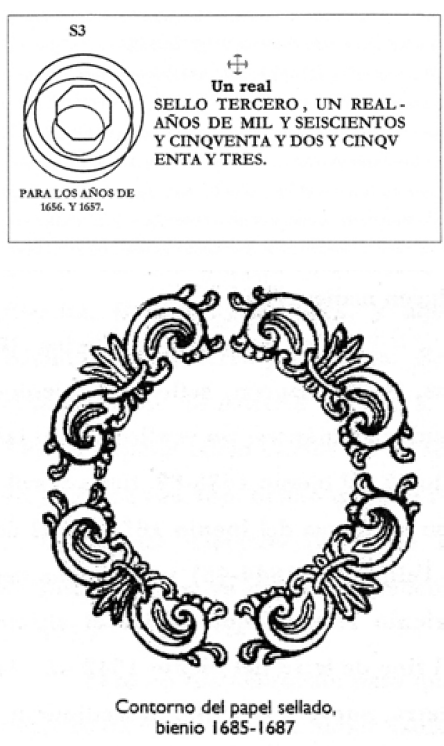

Figura 11. Esquema de resellos de los años 1656 y 1657 , y contorno de papel sellado del bienio 1685-1687. Ilustraciones en: El Papel sellado en el Perú Colonial (Peralta 2007).

...no solo cabe reflexionar sobre la importancia de la presencia del sello real en un papel que estuvo al alcance de todos a través del aparato del Estado, sino también en su aspecto estético. ${ }^{119}$

117 Corvera 2006: 46 .

118 Peralta 2007: 113, 137.

119 Ibíd.: 108. 
Se trata de un documento de valiosa utilidad para los exiguos estudios de heráldica, para la historia del ornato e historia del grabado virreinal.

Los restauradores Erman Guzmán y Gricel Serpa publican dos artículos en las Actas del ler Congreso de Historia y Cultura (2014) que realiza el SHRA en 2013. Por primera vez la disciplina de la Conservación y restauración de obras de arte abre un campo en la línea editorial del SHRA, donde la recuperación de la integridad estética, histórica y material cumple a su vez un papel de alerta patrimonial y novedad científica para la historia del arte peruano. De un lado Guzmán presenta el método y proceso interventivo a una portada de columnas salomónicas mutilada y conservada en un centro educativo de grado inicial perteneciente al Convento de Santo Domingo de Huancavelica (figura 12). De otro, Serpa revela el hallazgo de restos de pintura mural de s. XVII y XVIII en el Oratorio del Cristo de las Viñas, del Convento de San Francisco de Lima. Las exploraciones y métodos empleados por ambos autores, posiblemente contrastables, generan importantes materiales de estudio

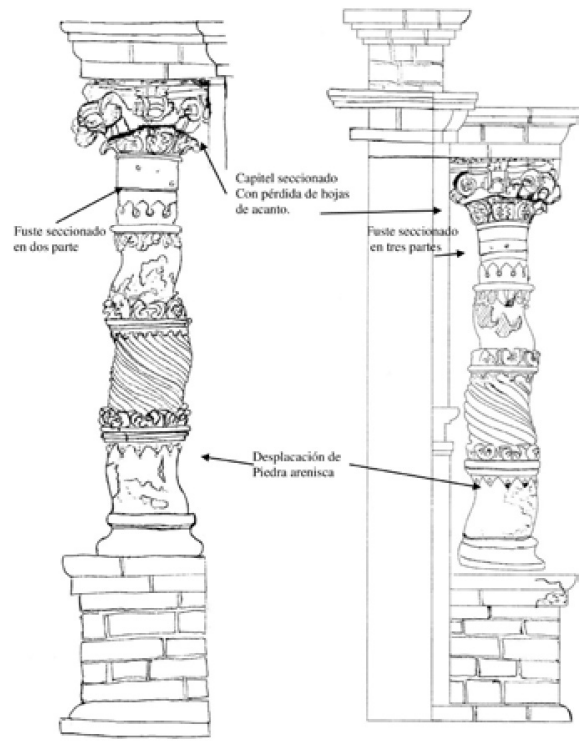

Figura 12. Esquemas trazados por el restaurador Erman Guzmán, donde indica el mapa daños a las columnas salomónicas. En: Actas del ler Congreso de Historia y Cultura (Rosario 2014). de arte virreinal. El SHRA abre entonces a través de esta iniciativa un nuevo horizonte de publicaciones e investigaciones de intercambiables aportes con la historia del arte.

\section{Arte republicano}

Entre 2002 y 2007 el SHRA impulsa la publicación de estudios en torno al arte del período republicano, representado durante sus primeras décadas por el género del retrato. En 2002, Patricia Mondoñedo publica El Retrato de José Olaya (1830?), un análisis historiográfico e iconográfico de una obra "disímil" en la producción del pintor afroperuano José Gil de Castro, considerada "obra maestra" dentro de su trayectoria internacional entre Perú, Chile y Argentina. Mondoñedo propone un progresivo acercamiento al significado social y político de la obra, primero a través de la revisión crítica de obras de arte latinoamericano que delatan la preferencia por el retrato entre las "nuevas necesidades estéticas"120 de la burguesía; segundo, a través de las causas que provocan el rápido desplazamiento del santoral cristiano por el panteón de héroes "revolucionarios" de la Independencia, tercero a través de ejemplos que demuestran la presencia de un repertorio iconográfico religioso entre los retratos, cuarto, a través de las características estilísticas que identifican a la pintura local y latinoamericana, tales como “. . la rigidez medieval, la obsesiva intensidad en la descripción de las texturas, recursos que... nuestros retratistas habían heredado del virreinato”, ${ }^{121}$ y quinto, a través de los aspectos formales e iconográficos que hacen del retrato de José Olaya una obra disímil o "extraorinaria", como el empleo del gran formato o grand portrait, sus implicancias sociales y políticas, su carácter monumental, su correspondencia naturalista con el paisaje de Chorrillos, y las connotaciones de clase que ostenta el atuendo festivo del pescador indígena.

120 Mondoñedo 2002: 17.

121 Ibíd.: 22. 
Entre la bibliografía hasta entonces escrita sobre José Gil de Castro, Mondoñedo es la primera que sustenta con argumentos documentales y algunos aspectos formales, la trascendencia estética e histórica de esta obra.

En 2005, bajo la asesoría de Leonardini, Angélica Brañez publica El vestido femenino limeño de elite durante la era del guano (1845-1878), tesis que sin pretensiones teóricas trata al vestido como fenómeno artístico, fruto de su tiempo y de sus condiciones culturales, equiparable con las artes clásicas. Identificado este por su principal aporte, abre nuevos campos de trabajo en torno a la secuencialidad de estilos del vestido y sus relaciones con el llamado "arte oficial". Al respecto, Leonardini señala en el prólogo:

Menospreciado por los investigadores tradicionalistas del arte que han manejado la historia de arte como historia de los artistas, como parte de la historia de las civilizaciones, como historia de las obras de arte o de los estilos, no resulta extraño que su desarrollos e historia sea manejada de soslayo y, por qué no decirlo, hasta con displicencia. Por otra parte ¿qué es lo que limita hasta ahora a los investigadores exentos de prejuicios en apreciar en su medida y sin miramientos el traje como parte de la historia del arte? No es otra cosa que una actitud subjetiva... ${ }^{122}$

El objeto de análisis de Brañez recae en "La tapada" y las causas estético-sociales que determinaron su reemplazo por los vestidos de moda francesa. Si bien es un proyecto investigativo que adolece del análisis directo de los vestidos, su metodología se inclina al estudio de las connotaciones sociales que poseen sus diseños y tipos de confección, por lo cual la historiadora del arte solo emplea referentes hemerográficos y fotográficos.

Similar metodología aplica Mary Takahashi en La pintura de miniatura en Lima durante la primera mitad del siglo XIX, tesis basada principalmente en la búsqueda documental de fuentes hemerográficas que revelan la intensa demanda de la miniatura, una variante del género retratístico practicada por los pintores limeños activos más importantes de las postrimerías virreinales. Las miniaturas seleccionadas y reproducidas por la investigadora demuestran un indiscutible juicio estético que pondera la calidad y expresividad empática de este género, no obstante, desde el punto de vista formal no propone análisis alguno que justifique este criterio.

Los hallazgos documentales son su principal aporte. A partir de los registros publicitarios en los periódicos limeños, Takahashi recopila un trascendente grupo de pintores miniaturistas locales (de Perú, Colombia y Ecuador), reunidos en una desventajosa competencia contra extranjeros (de Italia y Francia), quienes son contratados por una creciente clientela burguesa limeña, factor de clase que a su vez impone una escala de valores estéticos que justifican el mérito plástico y carácter testimonial de algunas miniaturas, como el de Francisca Zubiaga, "La Mariscala", uno de los pocos retratos de la mujer de un mandatario, reconocida además por su activa presencia en la vida política peruana y pública de Lima.

Hasta antes de 2006 el vestido y la miniatura son consideradas expresiones artísticas de clase menor, pese a su reconocida demanda comercial y trascendencia en la historia de la estética. A partir de los estudios que propone el SHRA ambos campos constituyen nuevas canteras de análisis, tal como la historiadora del arte Sofía Pachas introduce con una serie de publicaciones sobre la enseñanza artística en Lima decimonónica.

122 Brañez 2005:13. 
Con Doña Adelinda Concha de Concha... (2004), Pachas transcribe un expediente judicial con el cual se introduce a la biografía y patrimonio de Adelinda Concha, benefactora e impulsora de la investigación científica, la ética escolar y el desarrollo de las capacidades artísticas juveniles de Lima. Dos años después publica Los concursos de arte Concha (1890-1917), estudio historiográfico que reúne por primera vez las fuentes que revelan los objetivos de carácter ético y estético que condujeron a los jurados de los concursos de pintura y escultura financiados por A. Concha, antecedentes fundamentales para la fundación póstuma de la "Academia de Dibujo, Pintura y Escultura Adelinda Concha de Concha”, primera en la historia del arte peruano que institucionaliza la enseñanza de las artes plásticas antes de fundarse la Escuela Nacional de Bellas Artes (1919).

Revisados por separado los certámenes de dibujo, pintura, y escultura, Pachas hace una tipología temática de las obras concursantes, a fin de identificar los géneros y motivos más dominantes en la producción plástica limeña durante un período de reconquista económica del país tras su derrota con Chile en la guerra del guano y el salitre.

Las pesquisas documentales sobre los autores y obras concursantes, conducen a Pachas a encontrar un nuevo sendero investigativo cada vez más relacionado a la actividad del género femenino en la producción pictórica y escultórica de Lima.

En dos años más publica Las artistas plásticas de Lima, 1891-1918, estudio historiográfico y de género basado en la recopilación de fuentes hemerográficas que congrega un cuerpo de comentarios críticos referidos a las circunstancias sociales de la instrucción pública de mujeres, a las connotaciones sociales de su ejercicio artístico y a sus méritos estéticos. Citamos como ejemplo una opinión crítica sobre la Exposición Industrial de Lima (1869): "El bello sexo, ha tomado con ardor la idea de la exposición, y muchas de las mejores obras, son trabajadas por las delicadas manos de nuestras limeñas". ${ }^{123}$

Recopilados los nombres de las artistas limeñas más representativas hasta 1916, la investigadora esboza un diccionario que incluye además algunos nuevos nombres de artistas activas desde 1848, como los de Sabina Meucci, pariente del pintor Antonio Meucci, y una discípula anónima del pintor José Yañez. ${ }^{124}$

Después de los certámenes Concha y la fundación de la Academia, la enseñanza del dibujo, la pintura y la escultura son todavía un vacío inquietante para la historiadora del arte quien realiza dos publicaciones más en 2007 y 2010 acerca de las personalidades de Luis Ugarte Ronceros (1876-1948) y Antenor Borja, cruciales figuras en la enseñanza académica de las artes y la fundación de la Escuela Nacional de Bellas Artes del Perú.

En 2015 se publica Un retrato de Bolívar. Estudio introductorio a la obra de Pablo Roxas, tesis que además de retomar los estudios conmemorativos al Bicentenario de la República peruana, propone una metodología integral e interdisciplinaria para el análisis de una sola obra de arte. Mediante un enfoque historiográfico, formal e iconográfico, Esquivel analiza los condicionantes socio-históricos y plásticos que dieron origen al retrato de Simón Bolívar, una de las obras más importantes de este período realizada en 1825 por el pintor afroperuano Pablo Roxas.

Mediante documentos, el investigador explora la genealogía de los pintores coexistentes al período transicional del virreinato a la república, e identifica su estatus según su relación étnicosocial con los estamentos virreinales. A través de un contexto no antes escrito, el autor reconoce el

123 Pachas 2008: 52.

124 Ibíd.: 48. 
descentralizado trabajo que realizan los "pintores de transición"125 como decoradores festivos y de arquitectura, labor hasta ahora desprestigiada entre los estudiosos de este período.

Como parte de una estética escenográfica barroca, de ornato arquitectónico y festivo, Esquivel identifica a través de documentos y registros gráficos los condicionantes funcionales y simbólicos que dan materia a la "forma comprometida" ${ }^{26}$ del retrato de Bolívar con la Sala Capitular del edificio de la Municipalidad de Lima, un espacio civil de parafernalia votiva y religiosa, no antes estudiado.

A través de un metódico análisis formal el autor penetra en el lenguaje plástico de Roxas, con el cual identifica la falsedad del rostro de Bolívar en el lienzo tratado, así también atribuye y documenta dos obras más de Roxas. Certifica la validez de sus hipótesis mediante un examen de reflectografía infrarroja, método empleado por la disciplina de la conservación y restauración de obras de arte, con el cual determina la superposición de dos rostros en el retrato de Bolívar.

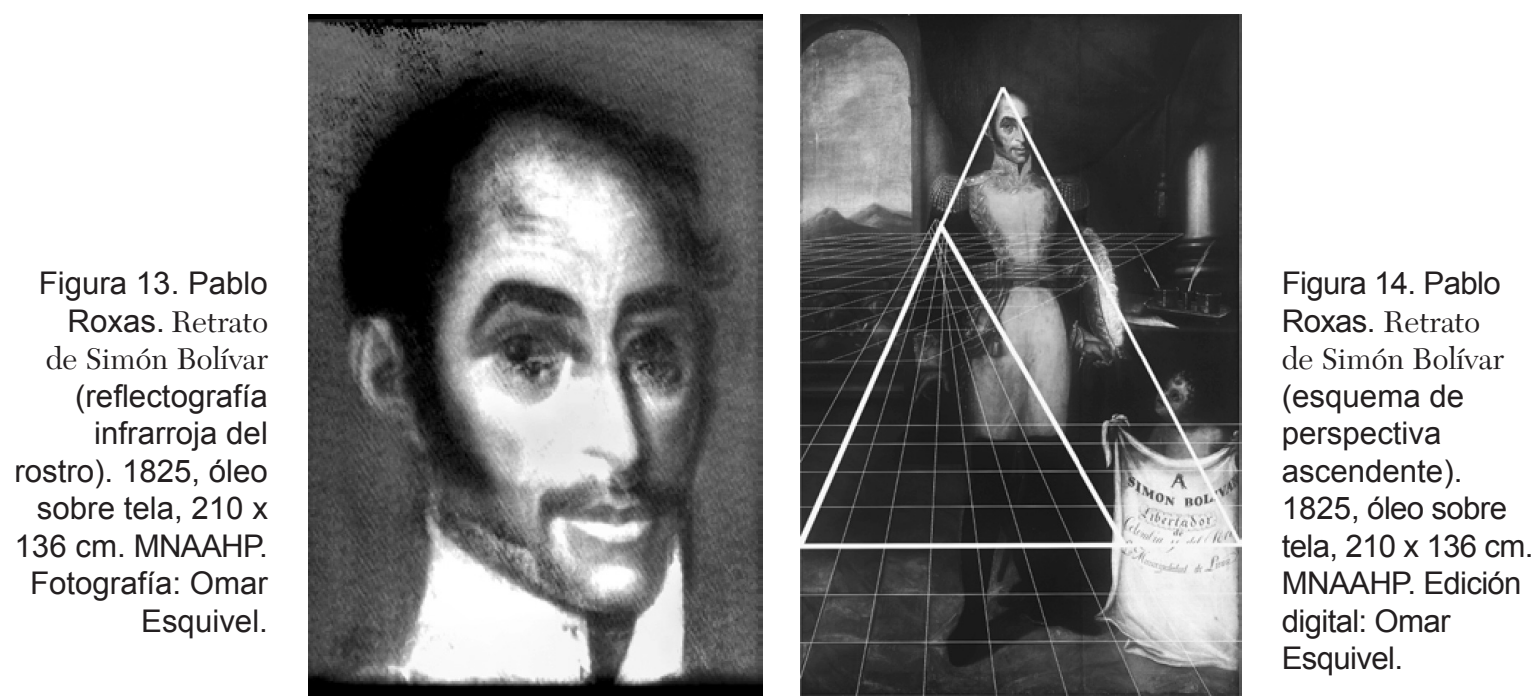

La relación entre los hallazgos formales y los componentes simbólicos del lienzo finalmente se funden en el proyecto de perspectiva ascendente que Roxas traza en el retrato de Bolívar, el mismo que guarda entre otras, dos connotaciones simbólicas: una institucional entre el niño que alegoriza la lealtad del municipio limeño al Libertador, y otra de carácter étnico-social, donde el Libertador de rasgos mestizos (o de casta), subordina al niño de rasgos europeos.

\section{Arte contemporáneo}

Analizar el presente supone un desprendimiento de los vínculos emocionales que consciente o inconscientemente están enraizados en nuestro juicio. El arte visto desde su contemporaneidad si bien requiere de un principio ideal de objetividad, sucumbe a las tendencias o ideologías en juego, por ello la miopía del presente suele ser un tabú entre los investigadores sobre cualquier campo relacionado con la política. El arte dentro de nuestra sociedad secularizada, lejos de ser un satélite, está estrechamente vinculado a ella gracias a su versatilidad social para representar las aspiraciones expresivas de las élites y de la ciudadanía, doble faceta que suele polarizarse en: aceptación y cen-

125 Esquivel 2015: 55

126 Ibíd.: 120. 
sura. Los trabajos publicados por el SHRA, si bien se acercan a la fina línea divisoria entre ambos campos, se inclinan por el rescate de la obra de artistas con indudable dominio plástico y laudable trayectoria nacional o internacional. Dieciocho de los veintidos trabajos realizados sobre arte contemporáneo ${ }^{127}$ se ocupan de producciones artísticas de segunda mitad de s. XX, los cuales incluyen géneros modernos como arte gráfico (publicitario, político y caricatura) y arte urbano. Repasaremos algunos títulos que han generado aportes significativos a la historia del arte contemporáneo del Perú.

Entre los trabajos artísticos editados por el SHRA, en su mayoría de arte popular y amazónico se suma Manco Inca (2001), primera publicación de una obra de arte gráfico escrita y dibujada a la tinta por el historiador Carlos Rojas Feria, quien a través de 164 viñetas narra la biografía y luchas de resistencia del último Inca de Vilcabamba, donde el montaje y la apropiación de grabados, esculturas, dibujos y pinturas son recursos visuales que iluminan su sentido hilarante basado en situaciones irreales, anacrónicas, satíricas y absurdas (figura 15).

Imagen y palabra articuladas en una obra con unidad significativa forman el binomio que define al arte gráfico como una propuesta documental y estética. Desde el lado documental, la lectura crítica que Rojas realiza de la vida de Manco Inca es un aporte al conocimiento masivo sobre las personalidades más importantes de la histórica resistencia cultural andina; desde el lado estético es un trabajo de carácter posmoderno que reúne las influencias de la caricatura estadounidense y peruana.

La personalidad y obra de Benjamín Mendoza resuena en los ambientes del SHRA. Su obra reconocida por Macera, Leo-

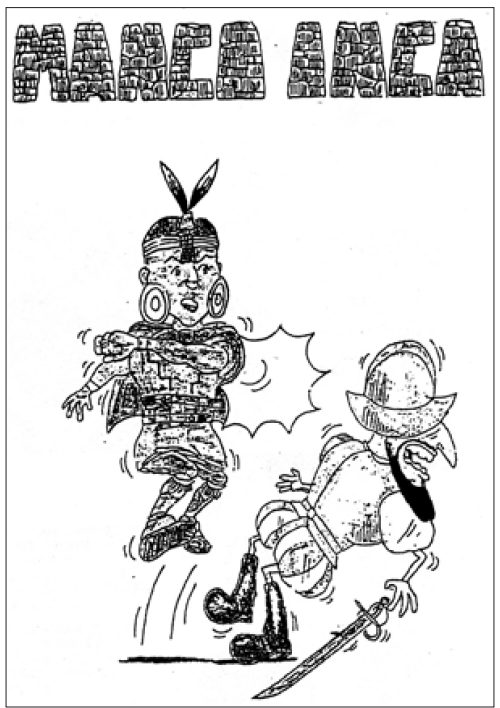

Figura 15. Dibujo de portada del libro Manco Inca (Rojas 2001), realizado por Carlos Rojas Feria. nardini y Pachas en Benjamín Mendoza. Fantasía y Jituikuntismo (2003), deja tres escritos donde cada autor vuelca en palabras las experiencias sensibles que estimula el simbolismo poético de Mendoza.

Leonardini considera a Mendoza un pintor univers al sin "nación” definida. Denomina a su obra como "poesía pictórica", 128 o armonía de metáforas íntimas y universales cuyo sentido onírico no es comparable con algún "ismo", sino trata de un estado mental que persigue la libre creatividad, o "Jituikuntismo".

El encuentro entre racionalidad e irracionalidad, figura y concepto, palabra e imagen en la obra de Mendoza no tiene escala de medida comparativa. A las impresiones de Leonardini se suma en esta misma sintonía las de Pablo Macera:

...la erótica y el surrealismo son conjugados en el trabajo magistral de Mendoza quien multiplica los espejos y las posibilidades de la realidad cotidiana para mostrarnos su trasrealidad, en el reino verdadero de la poesía. ${ }^{129}$

La misma inquietud poética de las aguadas de Mendoza motiva a Pachas a interpretar algunos términos del vocabulario poético del pintor:

12715 de ellos de autoría de Nanda Leonardini.

128 Leonardini 2003: 13

129 Ibíd.: 185 
La mujer es para Mendoza motivo relevante en su producción casi diríamos obsesivo... Su posición es ambigua al concebirlas; en ocasiones las muestra como una mujer fatal, poseedora de una sensualidad arrebatadora capaz de llevar a la locura y en otras demuestra ser un conocedor acérrimo de la psicología femenina, adentrándose en el sufrimiento, el abandono y el desamor de sus protagonistas. ${ }^{130}$

En forma de catálogo, las autoras contribuyen a la puesta en valor de la obra de Mendoza dentro del ámbito local e internacional:

...este modesto libro... encierra desesperadamente algunas de esas 120 obras realizadas entre 1990 y 1996, reproducidas en parte en esta edición, por razones técnicas y económicas, con ausencia de color. Ratificamos, desesperadamente, porque su amplia producción dispersa por todo el orbe, es inalcanzable; es entregar la punta de un iceberg, para atisbar un maravilloso universo fuera de lo usual en la plástica mundial. ${ }^{131}$

Biografía, trayectoria artística, reproducciones de obras y testimonios vivos son los principios metodológicos que también rigen Arte de la vida en riesgo (2004), libro coordinado por Leonardini que rescata la obra del grabador Félix Rebolledo Herrera, artista de indiscutibles cualidades y de antagónico perfil estético e ideológico al sistema de galerías de arte de Lima, cuyo estado marginal debió además sortear el peso represivo, la ignorancia y la irresponsabilidad del sistema judicial peruano. ${ }^{132}$ Sumido en constantes riesgos de ser anulado civil y artísticamente, al filo de la navaja de todo oficialismo y de su propia vida, este estudio incluye además las cartas y postales que demuestran la personalidad, sensibilidad, vivencias y circunstancias históricas que atraviesa Rebolledo.

En una semblanza cronológica y desde una postura formalista Angélica Brañez enfatiza la sensibilidad y el tratamiento plástico del grabador:

Los años de 1978 y 1979 constituyen uno de los momentos emocionales más agitados de toda su vida; hechos infortunados colman su creación de dolidas series. Así, la operación practicada a su hermano hacia 1978, donde pierde un ojo, inspira la serie A mi hermano Juan. El dolor es acentuado por el juego de sombras, solución plástica de clara tendencia expresionista. De esta manera aparece su hermano retratado en reposo luego de la intervención, con la bolsa de hielo sobre el ojo, sentado descansando, comiendo. El grito contenido y la amarga resignación son transmitidos por el autor con admirable destreza. ${ }^{133}$

A diferencia de los óleos, la reproductibilidad de su obra en este texto se aproxima a la apariencia original de sus valores monocromáticos (figura 16). ${ }^{134}$ Rescata en total 71 de sus grabados.

$\mathrm{Al}$ año siguiente Leonardini y Pachas publican Notas de arte (2005), libro que compila la obra artística y escrita de Gamaniel Palomino, grabador, dibujante, pintor y articulista limeño de temas periodísticos inclinados a los temas de su especialidad artística como el grabado, la crítica, la historia del arte peruano, latinoamericano y universal. En las páginas introductorias se señala:

130 Ibíd.: 16.

131 Ibíd.: 8

132 Denunciado por terrorista y encarcelado sin evidencias en el Penal de Lurigancho en junio de 1986, fallece el día 18 en un motín, a una semana de ser liberado. Su culpabilidad no fue probada.

133 Leonardini 2004: 32

134 Ibíd.: 21 
La nutrida y polifacética producción periodística de Gamaniel Palomino, difundida en revistas nacionales ya sea limeñas, chalacas y trujillanas, versa sobre arte, costumbrismo, deporte, historia, literatura, música, urbanismo. En esta oportunidad el Seminario de Historia Rural Andina, en su labor de rescatar personalidades que han hecho parte de la historia peruana, ha determinado publicar los textos de la primera disciplina por ser la más cercana a su quehacer profesional, aunque no siempre ilustrados debido a motivos de infraestructura y presupuestales. ${ }^{135}$

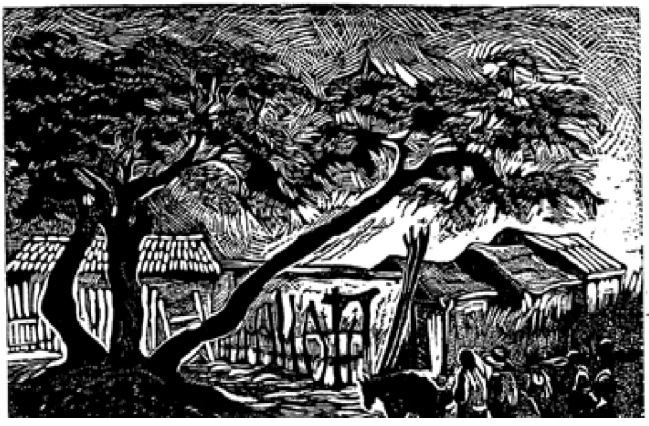

Figura 16. Después de laborar, xilografía de Félix Rebolledo. En: Arte de la vida en riesgo (Leonardini 2004).

En la primera mitad del texto, Leonardini, Pachas y tres allegados de "Don Gama" dejan una clara semblanza de su personalidad y versátil actividad en el medio artístico de Lima. Cabe destacar algunos comentarios críticos acerca de la preferencia técnica, temática y recursos plásticos de Palomino. Pachas señala:

La producción artística de Palomino se divide en una diversidad de disciplinas, técnicas y temas. Entre las primeras se encuentran el dibujo, la pintura y el grabado...Los temas circundan entre el retrato, los asuntos limeños, y serranos, el arte popular y los paisajes...

En grabado Gamaniel se distingue por el uso de diversas técnicas: así hallamos xilografías, serigrafía, punta seca, aguafuerte, linóleo, monotipa y litografía offset. Estas obras suelen ser de una calidad expresiva intensa cuando se trata de temas sociales como El Lustrabotas... El tema andino es tomado por Palomino en una de sus obras más logradas, Sembradoras. En esta imagen ha usado las líneas y las formas dándoles un carácter novedoso. ${ }^{136}$

La investigadora recalca además la relación entre el artista y su entorno étnico-social como parte de los motivos recurrentes de su obra:

Un buen ejemplo de la sensibilidad con la que Palomino capta la imagen de la mujer negra se encuentra en Las Sahumadoras... Inspirado en la tradición limeña de los procesión del Señor de los Milagros... No podemos dejar de mencionar las vistas de varios rincones de su querido Barrios Altos, distrito en el que nació y murió Palomino... ${ }^{137}$

Leonardini subraya la figura de Palomino dentro de la trayectoria histórica del arte gráfico nacional, donde su actividad lo convierte en heredero de la obra de Julio Málaga Grenet (figura 17)..$^{138}$

Desde los términos de Palomino el artista gráfico es un estudioso de la gestualidad y psicología del hombre, un dibujante con necesaria especialidad en el retrato:

135 Leonardini 2005: 13

136 Ibíd.: 23-25.

137 Ibíd.: 26-27.

138 Ibíd. : 38 
El caricaturista esencialmente es un gran psicólogo, es decir un acucioso observador de las diferentes formas externas e internas de las figuras humanas a través del trazo del dibujo, de la deformación o estilización, logra capturar la característica de la personalidad del personaje. ${ }^{139}$

La segunda mitad del texto transcribe los 75 artículos que Gamaniel Palomino publica entre agosto de 1950 y 9 de setiembre de 1990, testimonios de primera mano acerca de las actividades artísticas de Lima, donde destacan aquellos dedicados a José Sabogal, entre otros que incluyen nombres hasta entonces poco difundidos en la plástica nacional como el xilógrafo Eduardo Álvarez, los grabadores Evaristo San Cristóbal (s. XIX) y Ma-

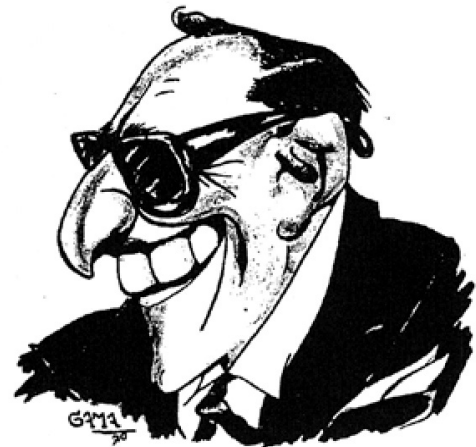

Figura 17. Luis Bedoya Reyes, dibujo a tinta sobre cartulina realizado por Gamaniel Palomino. En: Notas de arte (Palomino 2005). riano Alcántara, el pintor amazónico Fernando Sovero, el pintor huancaíno Guillermo Guzmán Manzaneda, el pintor limeño Manuel Zapata, los escultores Héctor Antonio Sánchez, Artemio Ocaña Bejarano, Ismael Pozo, David Lozano, René Pereira, Tancredi Pozzi y también a la ceramista Yolanda Díaz. Asimismo, incluye reseñas de instituciones trascendentales en la formación artística nacional, como la Escuela de Artes y Oficios, y la Academia "Adelinda Concha". Palomino aborda por lo tanto tópicos fundamentales que el entorno oficial del arte ignoraba o rezagaba de la historia del arte peruano.

En 2006 Leonardini publica La soledad y la forma título elegido en complicidad con Pablo Macera, en donde aborda la producción pictórica y grabados del arequipeño Miguel Espinoza Salas, artista de amplia trayectoria local e internacional con reconocibles aportes a la plástica peruana a nivel estético, teórico y de enseñanza, pero paradójicamente una de las figuras más olvidadas y representativas de la década de 1970 :

Sin lugar a dudas el nombre de Miguel Ángel Espinoza Salas, junto al del caricaturista José Vinatea Reynoso y al muralista Teodoro Núñez Ureta forma la trilogía en la historia del arte arequipeño del siglo XX. De manera simultánea, Miguel es para el grabado peruano de la segunda mitad del siglo XX uno de los más destacados artistas. Y por qué no decirlo, en la pintura, gracias a una acabada paleta, un dibujo impecable, una creatividad inspirada en la arquitectura y el entorno, el pintor más importante de su generación, en la época que le toca vivir. ${ }^{140}$

Bajo la misma estructura, la autora documenta la trayectoria de Salas y recopila tres escritos suyos, dos sobre mecanismos de aprendizaje en la pintura y uno sobre la historia del grabado. Pocos son los artistas que obtienen y sistematizan conocimientos suficientes para proponer métodos de enseñanza artística o para desarrollar algún aspecto de la plástica nacional, de aquí que la publicación de La experiencia de la luz, Historia del grabado y Sintáxis y metodología sean contribuciones valiosas para la historia del arte peruano. Leonardini señala:

Este hombre complejo, muy exigente con sí mismo, de oficio pulcro, estudioso en el color en la parte química, en la composición, en el dibujo, maneja además asuntos teóricos interesantes gracias a sus investigaciones sobre la luz, el grabado, la metodología de la enseñanza en las artes plásticas.

139 Citado por Leonardini. Ibíd.: 34.

140 Leonardini 2006: 10-11. 
Se trata nada menos que de una reconocida autoridad en materia artística, consultada en forma permanente por su medio. ${ }^{141}$

Con un total de 21 dibujos (figura 18), 19 óleos, 10 grabados y 1 acuarela, la historiadora del arte hace de este texto la mayor compilación de la obra de Miguel Espinoza Salas al mismo tiempo una muestra descentralizada que el SHRA realiza de la actividad artística contemporánea de nuestro país.

Antes de finalizar su directorio, Nanda Leonardini publica El poder de la imagen. Elecciones Municipales 2006, estudio colectivo publicado en formato digital que analiza la relación plástica entre los discursos visuales y políticos de los anuncios publicitarios producidos durante la campaña electoral municipal de 2006. Estrechamente ligado con el acontecer social, la investigadora examina fenómenos artísticos de la actualidad, premisa que ocupa un lugar importante en su diccionario de escultores, proyecto todavía en desarrollo, cuya primera fase consiste en publicaciones anuales que reúnen el testimonio directo de diversos escultores del ámbito nacional, quienes narran sus experiencias personales alrededor de su ejercicio artístico bajo la influencia de la sociedad

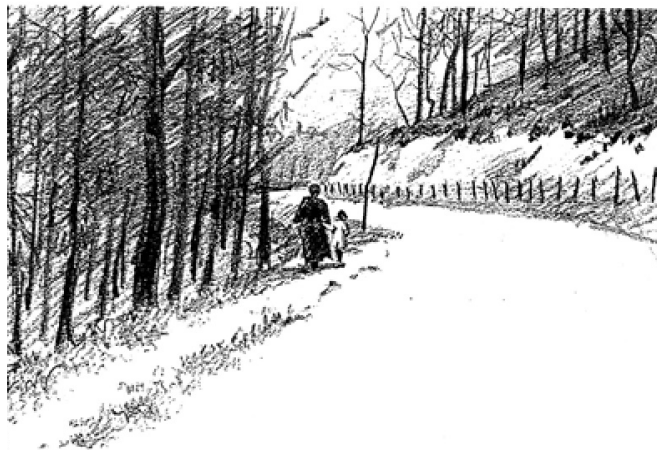

Figura 18. Sin título, dibujo hecho en carboncillo por Miguel Espinoza Salas. En: La soledad y la forma (Leonardini 2006). contemporánea.

Los testimonios basados en entrevistas realizadas por los alumnos de Leonardini, aplican un modelo de preguntas que en primer lugar se ocupa de los datos esenciales de cada artista, sus primeras inclinaciones hacia la escultura y su centro o medio de aprendizaje. En segundo, sobre su trayectoria, técnicas de producción, tendencias estéticas, y futuros proyectos. El resultado es un amplio expediente que desde 2010 a 2014 alcanza una suma de 190 testimonios, cada uno con una postura diferente sobre el quehacer escultórico.

El efecto de este proyecto renueva una lectura crítica de la escultura. Integra a los artistas según el tipo de obra que realizan y no de acuerdo a su procedencia social o formación plástica. No prevalece la diferencia entre el ceramista "popular” o el escultor de mármol, sino un crisol de estilos diversos colocados sobre un mismo horizonte, en un documento testimonial, sin duda, útil para cualquier artista plástico o ciudadano que desee informarse sobre la obra o la personalidad de los escultores. Es a su vez una fina herramienta investigativa que registra un instante de la producción escultórica nacional y que retrata las pretensiones estéticas de sus artífices en forma de expedientes biográficos disimulados bajo una pluma casual. En el primer volumen Leonardini señala:

Es un trabajo de índole testimonial, basado sólo en entrevistas a escultores peruanos vivos, con una trayectoria poco conocida o difundida. La idea implícita es hacer hablar a una gran parte de artistas que se han escapado del recuerdo formal y del reconocimiento que su obra merece dentro de los parámetros establecidos... Al entregar estos testimonios vivos impresos, pretendemos dar tribuna de voz a artistas soslayados, así como romper con los parámetros de bonito/feo, bueno/ malo, académico/no académico, occidental/popular, moderno/posmoderno, vocablos con los cuales se intenta apresar expresiones para dar contundentes juicios que, a pesar de su contundencia, no

141 Ibíd.: 39-40. 
les es factible detener un inmenso caudal de obras cuestionadas por un sector elítico (sic) que cree poseer la verdad. ${ }^{142}$

La introducción de cada volumen es un estudio histórico-crítico sobre los diferentes problemas que atraviesa el ejercicio de esta disciplina en nuestro país, entre ellos su interrelación con la crítica especializada y no especializada, la trayectoria histórica de la enseñanza escultórica y el incentivo económico de las instituciones estatales y privadas.

Sobre el primer problema la autora señala como caso más representativo la convivencia ciudadana con la escultura monumental. En 43 testimonios de escultores (2010) se anota:

En los últimos años algunos bronces de héroes o personajes históricos han sido robados para reciclar el preciado material. Con respecto al vandalismo los casos son diarios; estos van desde las intervenciones con graffiti a la mutilación, dormitorio de vagabundos, urinarios públicos, botadores de basura o destrucción política... Dentro del panorama descrito participan ladrones, recicladores, coleccionistas, autoridades con la complicidad muda de ciudadanos y estudiosos ocultos, estos últimos, tras el velo de la indiferencia. ${ }^{143}$

Hace hincapié además en el efecto educativo que la escultura pública ejerce en la formación del gusto de la ciudadanía:

Gracias a las 'inteligentes' gestiones de alcaldes improvisados se está formando el 'gusto' del ciudadano común que obligado -quiera o no- se encuentra en permanente contacto cuando, desde el transporte público, observa las esculturas en el paso diario camino al trabajo o de retorno a su casa, asumiendo que si el objeto se emplaza en un lugar privilegiado para enaltecer su presencia es porque ha logrado pasar las censuras bueno/malo, bonito/feo. Ante ello, comienza a gestarse nuevos patrones estéticos dentro de la población. ${ }^{144}$

La práctica local de la escultura, a diferencia de la pintura, se desarrolla en un entorno árido de posibilidades debido entre otros factores al estado precario de su enseñanza, restringido al corto número de escultores dedicados a esta labor, el cual ha forjado un vínculo de íntimas influencias entre alumno y maestro, una sucesiva cadena generacional de aprendizaje. En el estudio introductorio de Conversando con los escultores (2013), Leonardini realiza una reseña de las figuras históricas más importantes de la formación escultórica centralizada en Lima:

Para el interés de esta investigación destaca el taller de Jorge Piqueras Sánchez-Concha en la década de 1940 y el muy restringido de Victorio Macho. Pero, sin lugar a dudas uno de los más recordados es el de la escultora Cristina Gálvez lugar que, en la década de 1970 hasta 1981, fue paso obligado, de los artistas que quisieron perfeccionar sus técnicas de dibujo y escultura, habiéndose formado allí talentosos profesionales... A la muerte de Cristina [1982] el taller es retomado por una de sus alumnas, Margarita Checa, pero como la conducción es diferente, al poco tiempo desaparece. ${ }^{145}$

142 Leonardini 2010: 8-9

143 Ibíd.: 11

144 Ibíd.: 12

145 Leonardini 2013: 19. 
Entre otros espacios de enseñanza subraya la importancia de la Escuela de Artes Plásticas de la Pontificia Universidad Católica del Perú en la última mitad de s. XX:

Para el caso específico de la escultura, a partir de 1965 guía y dirige la especialidad la italiana Anna de Maccagno quien, formada en la misma universidad, conocía con toda propiedad al Perú, a su alma mater y al ambiente escultórico, por lo que su dirección es considerada de alta calidad. ${ }^{146}$

En un acápite final, Leonardini acusa el impacto directo del mercado y la post modernidad sobre la definición clásica de escultura, donde la reducción de "costos" empuja a la ruptura entre lo objetual y lo conceptual.

A esta coyuntura se le adjunta la exigencia externa de la permanente "originalidad". Quienes quieren entran en este juego, mezclan las disciplinas. De esta manera se presentan instalaciones donde interrelacionan junto a la escultura, la fotografía, el video, la música con iconografías de complejas lecturas que dejan al espectador confundido al no poder decodificar el significado ni separar las disciplinas... como señala Alfonso Castrillón: «Pienso que ponerlas en el nuevo Sistema "después del arte”, es más honesto y no se engañaría al público que, desde la época de las vanguardias, se ha sentido burlado». ${ }^{147}$

En su último volumen aborda como tercer problema el papel de las instituciones estatales y privadas para el fomento de una producción escultórica nacional, cuyo primera etapa se remonta al período 1891 y 1917 con los concursos trienales promovidos por Doña Adelinda Concha de Concha, donde las bases y las obras concursantes recalcan un notorio "contenido histórico y nacionalista", 148 entre las que destaca con elogios la Escultura a Ramón Castilla de David Lozano (1911), un retrato fiel y de "gallarda actitud". ${ }^{149}$ Se incluye también el último concurso realizado 10 años después, en 1927, cuando se elige ganadora la obra Los cachorros (figura 19), de Francisco Guzmán, discípulo de Artemio Ocaña.

Otra etapa demarca la creación del Premio Baltazar Gavilán en 1942, dedicado “....a la mejor obra escultórica sobre motivos nacionales", ${ }^{150}$ iniciativa estatal que en 1974, durante el gobierno de Velasco Alvarado, transfiere su organización al Instituto Nacional de Cultura, el cual galardona al año siguiente a Joaquín López Antay, hecho histórico que según señalamos líneas atrás, deja huella en las redefiniciones de arte y artesanía nacional Se incluye asimismo la paralela actividad crítica de los Salones de San Marcos (1951), los cuales incluyeron certámenes de escultura, que a diferencia de los concursos ya citados, estipularon adquirir las piezas ganadoras para nutrir el acervo patrimonial artístico de la Universidad Nacional de San Marcos. Entre otros se incluyen el Salón Nacional de Escultura del ICPNA (1986), así como los concursos convocados por el IPAE, el BCR y la Price Waterhouse Coopers, instituciones que con relativa regularidad han impulsado hasta la actualidad la práctica de esta disciplina. Nanda Leonardini acusa la importancia de documentar la trayectoria escultórica nacional a través de la adquisición y conservación de las piezas concursantes:

\footnotetext{
146 Ibíd.: 20.

147 Ibíd.: 21-22

148 Leonardini 2014: 14.

149 Calificativos citados de José Carlos Mariátegui. Ibíd.: 14-17.

150 Ibíd.: 24.
} 
...de una u otra manera existe continuidad en los premios para la escultura, continuidad lograda a través de concursos que nacen y fallecen con gran rapidez, pero que en cierto sentido dan dinamismo y estímulo al ambiente escultórico nacional. Por lo general de estas obras solo quedan los nombres de los creadores, a veces los títulos de las piezas, no siempre el material ni las medidas, circunstancialmente algunas fotografías, jamás su ubicación, convirtiéndose en objetos artísticos de leyenda, casi inexistentes para un estudio acucioso. Es un inmenso esfuerzo que ha quedado en el aire, desperdigado. ${ }^{151}$

Nanda Leonardini finalmente publica en 2015 el segundo título después de Notas de arte de Gamaniel Palomino, dedicados a la crítica de arte contemporáneo.

En una compilación de 79 artículos sobre arte llamada Crónicas de arte, escritos por Luis Varela Orbegoso "Clovis" publicados entre 1918 y 1929 a través de diversos medios pero principalmente en el diario El Comercio, la autora rescata el papel que ejerce el crítico de arte limeño en el ambiente artístico nacional.

El interés versátil por el circuito artístico limeño se comprueba en la relación de temas que aborda. Desde exposiciones realizadas en la capital, los acontecimientos alrededor de la arquitectura virreinal civil y religiosa, la semblanza de personalidades artísticas de su pasado inmediato como Luis Montero, Sebastián Lorente y Pancho Fierro, o de su día a día como de los pintores Daniel Hernández, Teófilo Castillo, Felipe Cossio del Pomar, Juan Lepiani, Olga Matellini, Carlos Baca-Flor, Enrique Barreda, Francisco González Gamarra, Ricardo Flórez, Alberto Lynch, Gauguin también llamado "pintor franco-peruano", 152 y Toribio Ponce paisajista arequipeño y

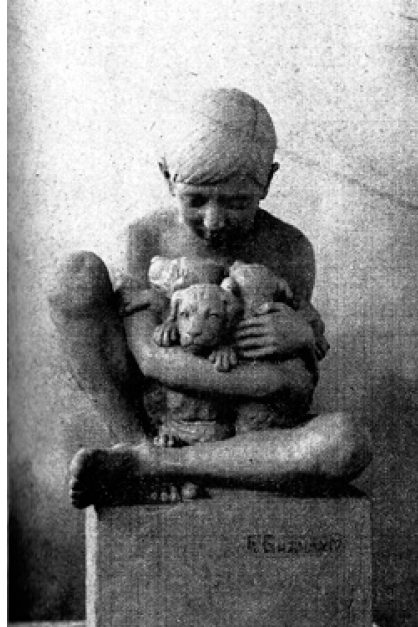

Figura 19. Fotografía de escultura Los Cachorros (1926), de Francisco Guzmán. Portada de Crónicas de arte, Luis Varela Orbegoso (Clovis) (2015). autodidacta "sobre quien la historia del arte peruano aún no ha hecho justicia”, ${ }^{153}$ el acuarelista Casimiro Cuadros, el dibujante Max León, el fotógrafo Enrique Reyes, los escultores David Lozano, Raúl Pro, Alberto Nalli, Luis Agurto, Francisco Guzmán e Ismael Pozo, y los arquitectos Emilio Harth-Terré, José Álvarez Calderón y Ricardo Malachowski, así también sobre el coleccionismo particular de las obras de arte de Pedro López Aliaga y Paul Berthon, o coleccionismo estatal de la Pinacoteca Municipal Ignacio Merino, todos dejan un importante cuerpo de documentos testimoniales para la historiografía del arte, entre los cuales además destacan aquellos que dan noticia sobre los activos espacios de exhibición artística. Sobre estos Leonardini señala:

Otro aspecto interesante desprendido de los escritos de Luis Varela Orbegoso está referido a los ambientes donde se realizan las exposiciones de arte. En total suman catorce y ninguno es una verdadera galería de arte o museo; se limitan a espacios gentilmente cedidos por particulares, la mayoría de ellos de pequeña envergadura, razón por la cual sólo es factible presentar un número reducido de obras.

151 Ibíd.: 54

152 Leonardini 2015: 186

153 Ibíd.: 40 . 
A través de las "Crónicas" se identifica el perfil de "Clovis", asiduo esteta entregado a un idílico pasado virreinal de enraizados valores éticos y religiosidad católica. Aunque Leonardini demuestra ser detractora de su personalidad, asiente que sus escritos “...resultan interesantes y recogen asuntos y comentarios eruditos que de otra manera se habrían perdido para la historia del arte peruano". ${ }^{154}$ Resume su polifacética pluma y ávido interés por las artes como el "aleteo fugaz de un ave en apresurado vuelo. ${ }^{155}$

\section{Epílogo}

A partir de la década de 1970, el interés efervescente de Macera por aproximarse a las conexiones historiográficas entre el arte "popular" y la mentalidad estética indígena colonial, permite incluir en su metodología analítica y discursiva los componentes formales de uno o un conjunto de piezas artísticas inéditas. La introducción de dicho interés, transversal a las publicaciones comprendidas hasta 2000, demuestra que la historia del arte ya había sido integrada al SHRA desde un ángulo metodológico auxiliar, cuya autonomía se obtiene durante la dirección de la historiadora del arte Nanda Leonardini.

El método de Macera para inducir la mentalidad amazónica a un proceso de expresión figurativa, deja una clara influencia entre los investigadores del SHRA, fruto de ello resultan las citadas investigaciones de María Belén Soria y Sofía Pachas sobre las pinturas de Roldán Pinedo y Elena Valera, y Gladis Masco, respectivamente. La metodología de Macera, por lo tanto, además de marcar una impronta personal en el perfil investigativo del SHRA, es transferida generacionalmente en sus actuales investigadores.

La filatelia, los esquemas de representación mariana, una sociedad en crisis expresada en un fenómeno estético, tal vez en uno o un conjunto de retratos durante la guerra de independencia criolla, o en el tardío reconocimiento de iniciativas ciudadanas para la educación artística decimonónica, el rescate del Jituikuntismo, del periodismo crítico de arte, del arte escultórico republicano y contemporáneo, del grabado y el arte gráfico de Lima, conforman un amplio mosaico de intereses académicos arraigados en el carácter crítico de la historiadora del arte Nanda Leonardini, publicaciones que dirigidas o escritas de mano propia, han propuesto un método aproximativo a las obras de arte a partir del estudio de su cotidianeidad y su compromiso social mediante el contacto directo con ellas, con el artista y con su entorno historiográfico. La trayectoria metodológica de la historia del arte en el SHRA por lo tanto hace de esta disciplina su indispensable continuidad y relación transdisciplinaria con sus demás áreas investigativas. 


\begin{tabular}{|c|c|c|c|c|c|c|c|c|c|c|c|c|c|c|c|c|c|}
\hline & \multicolumn{6}{|c|}{ Materia } & \multicolumn{8}{|c|}{ Disciplina científica } & \multicolumn{3}{|c|}{ Tipo } \\
\hline & 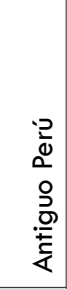 & 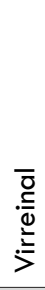 & 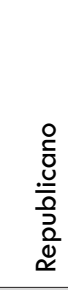 & 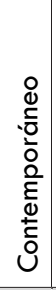 & $\frac{i}{\frac{1}{2}}$ & 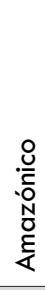 & $\begin{array}{l}\overline{0} \\
\frac{0}{0} \\
\frac{u}{0} \\
\sum\end{array}$ & $\begin{array}{l}\frac{0}{8} \\
\text { 응 } \\
0 \\
\frac{0}{0} \\
\frac{1}{4} \\
\frac{1}{4}\end{array}$ & $\begin{array}{l}\frac{0}{8} \\
\frac{0}{0} \\
0 \\
0 \\
\frac{0}{0} \\
\frac{1}{4}\end{array}$ & 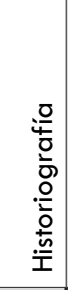 & 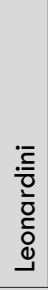 & $\stackrel{\frac{0}{4}}{\frac{1}{4}}$ & 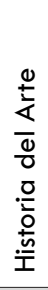 & 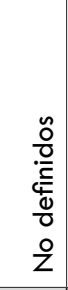 & 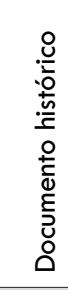 & 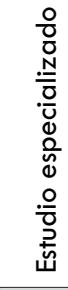 & 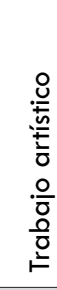 \\
\hline Quiroz : 1978 & & & & & $x$ & & & $x$ & & & & & & & $x$ & & \\
\hline Gushiken: 1979 & & & & & $x$ & & & $x$ & & & & & & & $x$ & & \\
\hline Rex: 1979 & $x$ & & & & & & & & $\mathrm{x}$ & & & & & & & $x$ & \\
\hline Morales: 1980 & $\mathrm{x}$ & & & & & & & & $x$ & & & & & & & $x$ & \\
\hline Morales: 1980 & $x$ & & & & & & & & $x$ & & & & & & & $x$ & \\
\hline Macera : 1980 & & & & & $\mathrm{x}$ & & $x$ & & & & & & & & & $x$ & \\
\hline Sayan: 1981 & & & & & $x$ & & & $x$ & & & & & & & $x$ & & \\
\hline Carbajal: 1981 & & & & & $\mathrm{x}$ & & & $x$ & & & & & & & $\mathrm{x}$ & & \\
\hline Echeandía: 1981 & & & & & $x$ & & & $x$ & & & & & & & $x$ & & \\
\hline Morales : 1981 & & & & & $x$ & & & $x$ & & & & & & & $x$ & & \\
\hline Valencia: 1981 & $x$ & & & & & & & & $\mathrm{x}$ & & & & & & & $x$ & \\
\hline Macera: 1981 & & & & & $x$ & & $x$ & & & & & & & & & $x$ & \\
\hline Macera: 1981 & & & & & $x$ & & $x$ & & & & & & & & & $x$ & \\
\hline Quiroz: 1981 & & & & & $\mathrm{x}$ & & & & & $x$ & & & & & & $x$ & \\
\hline De la Cruz: 1982 & & & & & $x$ & & & $x$ & & & & & & & $\mathrm{x}$ & & \\
\hline Echeandía: 1982 & & & & & $x$ & & & $x$ & & & & & & & $x$ & & \\
\hline Roel: 1982 & $x$ & & & & & & & & $x$ & & & & & & & $x$ & \\
\hline Morales: 1982 & $x$ & & & & & & & & $\mathrm{x}$ & & & & & & & $x$ & \\
\hline Gallarday: 1982 & $x$ & & & & & & & & $x$ & & & & & & & $x$ & \\
\hline Miasta: 1982 & $x$ & & & & & & & & $x$ & & & & & & & $x$ & \\
\hline Infantes : 1983 & & & & & $x$ & & & $x$ & & & & & & & $x$ & & \\
\hline Rengifo: 1983 & & & & & $x$ & & & & & & & & & $x$ & $\mathrm{x}$ & & \\
\hline Prada: 1984 & & & & & $x$ & & & $x$ & & & & & & & $x$ & & \\
\hline Luján: 1987 & & & & & $x$ & & & $x$ & & & & & & & $x$ & & \\
\hline Luján: 1987 & & & & & $x$ & & & $x$ & & & & & & & $\mathrm{x}$ & & \\
\hline Miasta: 1987 & & & & & $x$ & & & $x$ & & & & & & & $x$ & & \\
\hline Valencia: 1987 & $x$ & & & & & & & & $x$ & ! & & & & & & $x$ & \\
\hline Echeandía: 1990 & & & & & $x$ & & & $x$ & & & & & & & $x$ & & \\
\hline Macera: 1991 & & & $x$ & & & & $x$ & & & & & & & & $x$ & & \\
\hline Rodas: 1994 & & & & & $\mathrm{x}$ & & & & & & & & & $x$ & $x$ & & \\
\hline Rodas: 1994 & & & & & $x$ & & & & & & & & & $x$ & $x$ & & \\
\hline Berrocal: 1997 & & & & & $x$ & & & & & & & $x$ & & & & & $x$ \\
\hline
\end{tabular}




\begin{tabular}{|c|c|c|c|c|c|c|c|c|c|c|c|c|c|c|c|}
\hline Berrocal: 1997 & & & & & $x$ & & & & 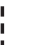 & $x$ & & & & & $\mathrm{X}$ \\
\hline Berrocal: 1997 & & & & & $x$ & & & & 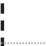 & $x$ & & & & & $\mathrm{X}$ \\
\hline Meseldzic: 1998 & & & & & $X$ & & & & 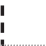 & & & $x$ & $x$ & & \\
\hline Meseldzic: 2000 & & & & & $\mathrm{x}$ & & & $x$ & & & & & $\mathrm{X}$ & & \\
\hline Leonardini: 2000 & & & & $x$ & & & & & $x$ & & & & $\mathrm{X}$ & & \\
\hline Cuentas: 2000 & $x$ & & & & & & & & 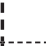 & & & $x$ & & $x$ & \\
\hline Churay: 2001 & & & & & & $x$ & $x$ & & 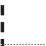 & & & & $\mathrm{X}$ & & \\
\hline Soria: 2001 & & & & & & $\mathrm{x}$ & $x$ & & 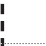 & & & & $x$ & & \\
\hline Rojas: 2001 & & & & $X$ & & & & & 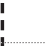 & $x$ & & & & & $\mathrm{x}$ \\
\hline Zárate: 2001 & & & & $X$ & & & & & 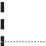 & $x$ & & & & & $\mathrm{X}$ \\
\hline Leonardini: 2001 & & & & $x$ & & & & & $x$ & & & & $\mathrm{x}$ & & \\
\hline Casanto: 2002 & & & & & & $\mathrm{X}$ & $\mathrm{x}$ & & 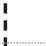 & & & & $X$ & & \\
\hline Condori: 2002 & & & & & $x$ & & $\mathrm{X}$ & & 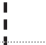 & & & & $\mathrm{X}$ & & \\
\hline Salinas: 2002 & & & $x$ & & & & & $x$ & 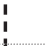 & & & & & $x$ & \\
\hline Tácunan: 2002 & & & & $\mathrm{X}$ & & & & & 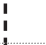 & $x$ & & & & & $\mathrm{X}$ \\
\hline Leonardini: 2002 & & & & $X$ & & & & & $x$ & & & & $\mathrm{X}$ & & \\
\hline Mondoñedo: 2002 & & & $x$ & & & & & & 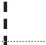 & & $\mathrm{x}$ & & & $\mathrm{X}$ & \\
\hline Jara: 2003 & & & & & $x$ & & $x$ & & 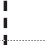 & & & & $\mathrm{x}$ & & \\
\hline Ríos: 2003 & & & & & & $\mathrm{X}$ & & & 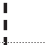 & $x$ & & & $\mathrm{X}$ & & \\
\hline Casanto: 2003 & & & & & & $\mathrm{X}$ & & & 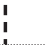 & $X$ & & & & & $\mathrm{X}$ \\
\hline Leonardini: 2003 & & & & $x$ & & & & & $x$ & & & & $\mathrm{x}$ & & \\
\hline Leonardini: 2003 & & & & $x$ & & & & & $x$ & & & & $x$ & & \\
\hline Soria: 2004 & & & & & & $\mathrm{x}$ & $x$ & & 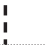 & & & & $\mathrm{X}$ & & \\
\hline Casanto: 2004 & & & & & & $x$ & & & 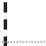 & $x$ & & & & & $\mathrm{x}$ \\
\hline Leonardini: 2004 & & & & $x$ & & & & & $x$ & & & & $\mathrm{X}$ & & \\
\hline Leonardini: 2004 & & & $x$ & & & & & & $x$ & & & & & $x$ & \\
\hline Pachas: 2004 & & & $x$ & & & & & & 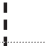 & & $x$ & & $x$ & & \\
\hline Debay: 2004 & & & $x$ & & & & & & 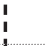 & & $\mathrm{x}$ & & $\mathrm{X}$ & & \\
\hline Mascco: 2004 & & & & & $x$ & & & & 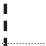 & & & $x$ & $X$ & & \\
\hline Casanto: 2005 & & & & & & $\mathrm{X}$ & & & 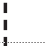 & $x$ & & & & & $\mathrm{X}$ \\
\hline Leonardini: 2005 & & & & $x$ & & & & & $x$ & & & & $x$ & & \\
\hline Sierra: 2005 & & & & & $x$ & & & & 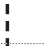 & & $x$ & & $X$ & & \\
\hline Brañez: 2005 & & & $X$ & & & & & & 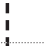 & & $x$ & & & $X$ & \\
\hline Ugarte: 2005 & & & $x$ & & & & & & 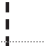 & & $x$ & & $\mathrm{X}$ & & \\
\hline Casanto: 2006 & & & & & & $\mathrm{x}$ & & & 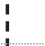 & $x$ & & & & & $x$ \\
\hline Leonardini: 2006 & & & & $\mathrm{x}$ & & & & & $x$ & & & & $x$ & & \\
\hline Corvera: 2006 & & $X$ & & & & & & & ! & & $x$ & & & $x$ & \\
\hline Pachas: 2006 & & & $x$ & & & & & & 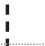 & & $x$ & & $X$ & & \\
\hline Takahashi: 2006 & & & $x$ & & & & & & ! & & $\mathrm{x}$ & & $X$ & & \\
\hline Peralta: 2007 & & $X$ & & & & & & $x$ & ! & & & & $x$ & & \\
\hline Casanto: 2007 & & & & & & $X$ & & & 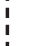 & $x$ & & & & & $x$ \\
\hline
\end{tabular}




\begin{tabular}{|c|c|c|c|c|c|c|c|c|c|c|c|c|c|c|c|c|c|}
\hline Pachas: 2007 & & & & & & $x$ & & & & & & $x$ & & & & & $x$ \\
\hline Leonardini: 2007 & & & & $x$ & & & & & & & $x$ & & & & & $x$ & \\
\hline Pachas: 2007 & & & $x$ & & & & & & & & & & $x$ & & $x$ & & \\
\hline Casanto: 2008 & & & & & & $x$ & & & & & & $x$ & & & & & $x$ \\
\hline Solórzano: 2008 & & & & & & $x$ & & & & & & & $x$ & & $x$ & & \\
\hline Pachas: 2008 & & & $x$ & & & & & & & & & & $x$ & & $x$ & & \\
\hline Mallma: 2009 & & & & $x$ & & & & & & $x$ & & & & & & $x$ & \\
\hline Tácunan: 2009 & & & & $x$ & & & & & & & & $x$ & & & & & $x$ \\
\hline Casanto: 2009 & & & & & & $x$ & & & & & & $x$ & & & & & $x$ \\
\hline Soria: 2009 & & & & & & $x$ & & $x$ & & & & & & & & & $x$ \\
\hline Pachas: 2009 & & & $x$ & & & & & & & & & & $x$ & & $x$ & & \\
\hline Corvera: 2009 & & $x$ & & & & & & & & & & & $x$ & & & $x$ & \\
\hline Soria: 2009 & & & & & & $x$ & & $x$ & & & & & & & & $x$ & \\
\hline Soria: 2010 & & & & & & $x$ & & $x$ & & & & & & & $x$ & & \\
\hline Casanto: 2010 & & & & & & $x$ & & & & & & $x$ & & & & & $x$ \\
\hline Tácunan: 2010 & & & & $x$ & & & & & & & & $x$ & & & & & $x$ \\
\hline Leonardini: 2010 & & & & $x$ & & & & & & & $x$ & & & & $x$ & & \\
\hline Leonardini: 2010 & & & & $x$ & & & & & & & $x$ & & & & $x$ & & \\
\hline Salinas: 2010 & & & $x$ & & & & & & & $x$ & & & & & & $x$ & \\
\hline Pachas: 2010 & & & $x$ & & & & & & & & & & $x$ & & $x$ & & \\
\hline Núñez: 2012 & & & & & $x$ & & & & & $x$ & & & & & $x$ & & \\
\hline Leonardini: 2012 & & & & $x$ & & & & & & & $x$ & & & & $x$ & & \\
\hline Casanto: 2013 & & & & & & $x$ & & & & & & $x$ & & & & & $x$ \\
\hline Leonardini: 2013 & & & & $x$ & & & & & & & $x$ & & & & $x$ & & \\
\hline Rengifo: 2014 & & & $x$ & & & & & & & $x$ & & & & & & $x$ & \\
\hline Peralta: 2014 & & & & $x$ & & & & & & $x$ & & & & & $x$ & & \\
\hline Leonardini: 2014 & & & & $x$ & & & & & & & $x$ & & & & $x$ & & \\
\hline $\begin{array}{l}\text { Serpa y Guzmán: } \\
2014\end{array}$ & & $x$ & & & & & & & & & & & $x$ & & & $x$ & \\
\hline Leonardini: 2015 & & & & $x$ & & & & & & & $x$ & & & & $x$ & & \\
\hline Esquivel: 2015 & & & $x$ & & & & & & & & & & $x$ & & & $x$ & \\
\hline \multirow[t]{2}{*}{ Echevarría: 2015} & $x$ & & & & & & & & & & & & $x$ & & & $x$ & \\
\hline & 11 & 4 & 17 & 22 & 31 & 19 & 4 & 23 & 9 & 9 & 16 & 19 & 18 & 6 & 57 & 28 & 19 \\
\hline
\end{tabular}




\section{Bibliografía}

Berrocal, Carmelón, Pablo Macera y Rosaura Andazabal (1997a). Cuentos pintados del Perú/Pirumanta llinpisqa willakuykuna. Sarhua n. ${ }^{\circ}$ 3. Lima: Seminario de Historia Rural Andina, Universidad Nacional Mayor de San Marcos. Dirección Nacional de Formación y Capacitación Docente, Ministerio de Educación del Perú. Deutsche Gesellschaft Für Technische Zusammenarbeit (GTZ) GMBH.

Berrocal, Carmelón, Pablo Macera y Rosaura Andazabal (1997b). Cuentos pintados del Perú/Pirumanta llinpisqa willakuykuna. Sarhua n. ${ }^{\circ}$ 4. Lima: Seminario de Historia Rural Andina, Universidad Nacional Mayor de San Marcos. Dirección Nacional de Formación y Capacitación Docente, Ministerio de Educación del Perú. Deutsche Gesellschaft Für Technische Zusammenarbeit (GTZ) GMBH.

Berrocal, Carmelón, Pablo Macera y Rosaura Andazabal (1997c). Cuentos pintados del Perú/Pirumanta llinpisqa willakuykuna. Sarhua n. ${ }^{\circ}$ 5. Lima: Seminario de Historia Rural Andina, Universidad Nacional Mayor de San Marcos. Dirección Nacional de Formación y Capacitación Docente, Ministerio de Educación del Perú. Deutsche Gesellschaft Für Technische Zusammenarbeit (GTZ) GMBH.

Brañez, Angélica (2005). El vestido femenino limeño de elite durante la era del guano (1845-1878). Lima: Seminario de Historia Rural Andina, Universidad Nacional Mayor de San Marcos.

Carbajal C., Rubén (1981). Fiesta del Niño Perdido. Folklore musical de Huancavelica. Serie Historia Andina n. ${ }^{\circ}$ 7. Lima: Dirección Universitaria de Proyección Social, Universidad Nacional Mayor de San Marcos.

Casanto Shingari, Enrique y María Belén Soria (2002). Arte y Cultura del Monte. Asháninca del Perené. Lima: Seminario de Historia Rural Andina, Universidad Nacional Mayor de San Marcos.

Casanto Shingari, Enrique (2003). Sankenarentsi opoñaanaka kinkitsarentsi. Escritura y cuento. Lima: Seminario de Historia Rural Andina, Universidad Nacional Mayor de San Marcos.

Casanto Shingari, Enrique, Gladis Mascco, Robert Rengifo y Romer Yagkug (2004). La otra historia. Héroes populares del Perú. Lima: Seminario de Historia Rural Andina, Universidad Nacional Mayor de San Marcos.

Casanto Shingari, Enrique (2005). Piri Piri. Plantas medicinales. Lima: Seminario de Historia Rural Andina, Universidad Nacional Mayor de San Marcos.

Casanto Shingari, Enrique (2006). Naturaleza amenazada. Lima: Seminario de Historia Rural Andina, Universidad Nacional Mayor de San Marcos.

Casanto Shingari, Enrique (2007). Las pitucas y otras plantas medicinales de la Amazonía. Lima: Seminario de Historia Rural Andina, Universidad Nacional Mayor de San Marcos.

Casanto Shingari, Enrique (2008). Plantas medicinales para pescar en la selva amazónica. Lima: Seminario de Historia Rural Andina, Universidad Nacional Mayor de San Marcos.

Casanto Shingari, Enrique (2009). Plantas para cazar de la Amazonia peruana. Lima: Seminario de Historia Rural Andina, Universidad Nacional Mayor de San Marcos.

Casanto Shingari, Enrique (2010). Frutos comestibles de nuestra Amazonia. Lima: Seminario de Historia Rural Andina, Universidad Nacional Mayor de San Marcos.

Casanto Shingari, Enrique (2013). Canciones Ashánincas. Lima: Seminario de Historia Rural Andina, Universidad Nacional Mayor de San Marcos.

Churay Flores, Víctor y María Belén Soria Casaverde (coord.) (2001). Fiestas tradicionales de los 
Bora. Lima: Seminario de Historia Rural Andina, Universidad Nacional Mayor de San Marcos.

Condori, Félix. Narrador-pintor y Rosaura Andazabal, Recopilación e investigación. Lagos, Demonios y Serpientes. Narraciones aimaras. Lima: Seminario de Historia Rural Andina, Universidad Nacional Mayor de San Marcos, 2002. 208 p.

Corvera, Marcela (2006). El Patrocinio. Una leyenda y un esquema artístico medievales ampliamente desarrollados en el virreinato peruano y aún, en la época republicana. Lima: Seminario de Historia Rural Andina, Universidad Nacional Mayor de San Marcos.

Corvera, Marcela (2009). El Antiguo Testamento en el arte del Virreinato peruano. Lima: Seminario de Historia Rural Andina, Universidad Nacional Mayor de San Marcos.

Cuentas, Karina (2000). Esquemas visuales, dos experiencias de percepción. Lima: Seminario de Historia Rural Andina, Universidad Nacional Mayor de San Marcos.

Debay, A. (2004). Las modas y los adornos. Chabot, Traducción del francés. Lima: Seminario de Historia Rural Andina, Universidad Nacional Mayor de San Marcos.

De la Cruz Fierro, Juan (1982). Folklore Andino I. Lima: Seminario de Historia Rural Andina, Universidad Nacional Mayor de San Marcos.

Echeandía Valladares, Juan (1981). La artesanía en el Bajo Piura. Serie Historia Andina n. ${ }^{\circ} 8$. Lima: Seminario de Historia Rural Andina, Universidad Nacional Mayor de San Marcos.

Echeandía Valladares, Juan (1982). Alfarería tradicional en Taricá (Áncash). Serie Historia Andina n. ${ }^{\circ}$ 16. Lima: Seminario de Historia Rural Andina, Universidad Nacional Mayor de San Marcos.

Echeandía Valladares, Juan y Renate Wisbar (1990). Los ceramistas de Piura. Lima: Seminario de Historia Rural Andina, Universidad Nacional Mayor de San Marcos.

Echevarría López, Gori (2015). Rimacc Rumi. Las Antiguas Quilcas de Lima. Lima: Seminario de Historia Rural Andina, Universidad Nacional Mayor de San Marcos.

Esquivel Ortiz, Omar (2015). Un retrato de Bolívar. Estudio introductorio a la obra de Pablo Roxas. Lima: Seminario de Historia Rural Andina, Universidad Nacional Mayor de San Marcos.

Gallarday, Tomás (1982). Arcillas de la costa central peruana (Cuenca del río Chancay). Serie Historia Andina n. ${ }^{\circ}$ 15. Lima: Seminario de Historia Rural Andina, Universidad Nacional Mayor de San Marcos.

Gushiken, José I. (1979). El violín de Isua. Biografía de un intérprete de música folklórica. Lima: Seminario de Historia Rural Andina, Universidad Nacional Mayor de San Marcos.

Guzmán Reyes, Erman (2014). "Portada con columna salomónica en la I.E.I. n. ${ }^{\circ} 107$ del Convento de Santo Domingo, ciudad de Huancavelica”. En: Rosario, Emilio. Actas del 1er Congreso de Historia y Cultura. Lima: Seminario de Historia Rural Andina, Universidad Nacional Mayor de San Marcos.

Infantes Saavedra, Priciliano (1983). Mi pueblito (Sartimbamba). Lima: Seminario de Historia Rural Andina, Universidad Nacional Mayor de San Marcos.

Jara Palacios, Leonidas y Rosaura Andazábal (2003). Testimonio de vida. Lima: Seminario de Historia Rural Andina, Universidad Nacional Mayor de San Marcos.

Leonardini, Nanda (coord.) (2000). Arte peruano del siglo XX, Cronología. Lima: Seminario de Historia Rural Andina, Escuela de Arte- Universidad Nacional Mayor de San Marcos.

Leonardini, Nanda (coord.) (2001). Pintura Mural Peruana, Siglo XX (Catálogo). vol. 1. Lima: 
Seminario de Historia Rural Andina, Facultad de Letras y Ciencias Humanas, Escuela de Arte, Universidad Nacional Mayor de San Marcos.

Leonardini, Nanda (coord.) (2001). Pintura Mural Peruana, Siglo XX (Catálogo). vol. 2. Lima: Seminario de Historia Rural Andina, Facultad de Letras y Ciencias Humanas, Escuela de Arte, UNMSM.

Leonardini, Nanda, David Rodríguez, Virgilio Freddy Cabanillas (comps.) (2004). Imagen de la muerte. Primer Congreso Latinoamericano y Ciencias Sociales y Humanidades. Lima: Fondo Editorial de la Universidad Nacional Mayor de San Marcos.

Leonardini, Nanda (2003). Zárate. Dibujos. Lima: Seminario de Historia Rural Andina, Universidad Nacional Mayor de San Marcos.

Leonardini, Nanda y Sofía Pachas Maceda (2003). Benjamín Mendoza. Fantasía y Jituikuntismo. Lima: Seminario de Historia Rural Andina, Universidad Nacional Mayor de San Marcos.

Leonardini, Nanda y Angelica Brañez (2004). Arte de la vida en riesgo. Félix Rebolledo. Lima: Seminario de Historia Rural Andina, Universidad Nacional Mayor de San Marcos.

Leonardini, Nanda (2006). La soledad y la forma. La obra plástica de Miguel Espinoza Salas. Lima: Seminario de Historia Rural Andina, Universidad Nacional Mayor de San Marcos.

Leonardini, Nanda (coord.) (2007). El poder de la imagen. Elecciones Municipales 2006. Lima: Seminario de Historia Rural Andina, Universidad Nacional Mayor de San Marcos, formato digital (CD-DVD).

Leonardini, Nanda (coord. y ed.) (2010a). 43 Testimonios de escultores. Lima: Seminario de Historia Rural Andina, Universidad Nacional Mayor de San Marcos.

Leonardini, Nanda (comp. y ed.) (2010b). Textos de Arte en la revista Casa de las Américas (19601969). Lima: Seminario de Historia Rural Andina, Universidad Nacional Mayor de San Marcos.

Leonardini, Nanda (coord. y ed.) (2012). Hablan los escultores. Lima: Perú, Grupo de Estudios Guanahaní-Seminario de Historia Rural Andina, Universidad Nacional Mayor de San Marcos.

Leonardini, Nanda (coord. y ed.) (2013). Conversando con los escultores. Lima: Seminario de Historia Rural Andina, Universidad Nacional Mayor de San Marcos.

Leonardini, Nanda (coord. y ed.) (2014). Diálogo con los escultores. Lima: Seminario de Historia Rural Andina, Universidad Nacional Mayor de San Marcos.

Leonardini, Nanda (2015). Crónicas de Arte. Luis Varela Orbegoso (Clovis). Lima: Seminario de Historia Rural Andina, Universidad Nacional Mayor de San Marcos.

Luján, Flor (1987). Artesanía en piedra de Huamanga. Lima: Seminario de Historia Rural Andina, Universidad Nacional Mayor de San Marcos.

Luján Vargas, Mary (1987). Artesanía en madera (Huamanga-Ayacucho). Lima: Seminario de Historia Rural Andina, Universidad Nacional Mayor de San Marcos.

Macera, Pablo (1980). Arte y lucha social: Los murales de Ambaná (Bolivia). Lima: Seminario de Historia Rural Andina, Universidad Nacional Mayor de San Marcos.

Macera, Pablo (1981a). Retablos andinos. Serie Historia Andina n. ${ }^{\circ} 4$. Lima: Seminario de Historia Rural Andina, Universidad Nacional Mayor de San Marcos.

Macera, Pablo (1981b). Joaquín López Antay. Serie Historia Andina n. ${ }^{\circ}$ 9. Lima: Seminario de Historia Rural Andina, Universidad Nacional Mayor de San Marcos.

Macera, Pablo (1991). Teatro peruano, siglo XIX. Fuentes de Historia Social Americana vol. 21. Lima: Seminario de Historia Rural Andina, Universidad Nacional Mayor de San Marcos. 